International Journal of Politics and Security (IJPS)

ISSN: $2667-8268$

https://dergipark.org.tr/tr/pub/ijps

Amerikan Hegemonyasının Son Dönemlerdeki Seyri ve Çin’in Yükselişi

Yazar(lar) / Author(s): Cengiz DİNÇ - Onur YURDABAK

Kaynak / Source: International Journal of Politics and Security (IJPS) / Cilt. 3 / Say1. 3 / Ekim. 2021, ss. 332-368.

DOI: $10.53451 /$ ijps.944671

Geliş Tarihi / Date of Arrival : : 29.05.2021

Kabul Tarihi / Date of Acceptance : 28.06.2021

Bu Makaleye Atıf İçin / To cite this article:

Dinç, Cengiz ve Onur Yurdabak. "Amerikan Hegemonyasının Son Dönemlerdeki Seyri ve Çin'in Yükselişis”. International Journal of Politics and Security (IJPS), Cilt. 3, Say1. 3, 2021, ss. 332-368, DOI: 10.53451/ijps.944671

Bu makalenin tüm hakları International Journal of Politics and Security (IJPS) Dergisi'ne aittir. Önceden yazılı izin almadan hiçbir iletişim, kopyalama ya da yayın sistemi kullanılarak yeniden yayımlanamaz, çoğaltılamaz, dağıtılamaz, satılamaz veya herhangi bir şekilde kamunun ücretli/ücretsiz kullanımına sunulamaz. Akademik amaçlı alıntılar bu kuralın dışındadır. Yazıda belirtilen fikirler yalnızca yazarına/yazarlarına aittir. 


\title{
Amerikan Hegemonyasının Son Dönemlerdeki Seyri ve Çin’in Yükselişi
}

\author{
Cengiz DİNÇ* \\ Onur YURDABAK ${ }^{* *}$
}

\section{$\ddot{O} z$}

Uluslararası ilişkilerde güncel konulardan birisi, Amerika Birleşik Devletleri'nin (ABD) hegemonik konumudur. Sovyet Sosyalist Cumhuriyetler Birliği’nin (SSCB) dağılmasının ardindan iki kutuplu uluslararası sistemin ABD'nin hâkim olduğu tek kutuplu sisteme dönüşmesi sonrasında, 90'll ylllardan itibaren ABD hegemonyasının sürdürülebilirliği önemli bir tartışma konusu olmuştur. Çin'in özellikle 21. yüzyıl itibarıyla, Soğuk Savaş sonrasında oluşturulan Pax Americana'nın kurumları ve kurallarına rızayı seçmek yerine belirli konularda kendi çıkarları adına hareket ederek kendi uluslararası sistemini kurmaya çalıştı̆̆ bilinmektedir. Dış politikasını büyük ölçüde küresel hegemonyasını devam ettirmek üzerine kuran ABD ise geçmiş dönemlerde SSCB ile yaşadı̆̆ rekabetin bir benzerini 2020 'lerde Çin'le yaşamaktadır. Her ne kadar 21. yüzyılda yaşanılan güç dönüşümüyle ABD'nin gücü göreli olarak azalırken, Çin'inki artmaktaysa da, ABD'nin ekonomik, askeri ve teknolojik üstünlükleri nedeniyle küresel hegemonyasına son vermenin çok uzun zaman alacağı görüsü, politika yapıcılar ve uluslararası ilişkiler akademisyenleri arasında yaygındır. Bununla birlikte, Çin'in yükselişi, 21. Yüzyllın ikinci çeyreğinden itibaren de ABD'nin dış politikasının en önemli meselesi olacaktır. Bu çalışmada kapsamlı bir literatür taraması ışığında hegemonyanın sert ve yumuşak güç unsurları ele alınarak ABD ve Çin karşılaşstırılması yapılmış, hiçbir hegemonik düzenin sonsuza dek sürmeyeceği düşüncesiyle, yaşanılan yapısal değişimlerin Amerikan hegemonyasını nereye taşıyacağı, mevcut 'gü̧̧ kayması' ve ABD'nin hegemonik düşüşte olup olmadiğına dair görüşler analiz edilmiştir.

Anahtar Kelimeler: Amerika Birleşik Devletleri, Çin Halk Cumhuriyeti, Hegemonya, Amerikan Hegemonyası, Çin'in Yükselişi

\section{Recent Progress of American Hegemony and the Rise of China Abstract}

One of the current issues in international relations is the hegemonic position of the United States of America (USA). After the collapse of the Soviet Union (USSR) and the transformation of the bipolar international system into a unipolar USA-dominated system, the sustainability of the US hegemony has been an important topic of discussion. China, especially in the 21st century, has been trying to establish its own international system by acting on behalf of its own interests in certain issues rather than consenting to the institutions and rules of the Pax Americana, which were created after the Cold War. The USA, which has based its foreign policy largely on maintaining its global hegemony, is experiencing a competition with today's China, similar to the competition it had with the USSR in the past. Although the US power declines relatively with the power transformation in the 21st century as China's rises, many policymakers and international relations academics share the view that it will take a long time to end the global US hegemony due to the economic, military, and technological superiorities. Nevertheless, the rise of China would stay as the most important issue of US foreign policy in the coming years. With an extensive look on the literature, this study compares the US and China using the hard and soft power instruments of hegemony. Keeping in mind that no hegemonic order will last forever, the views on the current 'power shift', where the structural changes will lead American hegemony and whether the US is in a hegemonic decline are also analysed.

Key Words: United States of America, The People's Republic of China, Hegemony, American Hegemony, Rise of China

\footnotetext{
*Doç. Dr., Osmangazi Üniversitesi, Uluslararası Siyaset Anabilim Dalı, cdinc@gogu.edu.tr, ORCID: 00000002-4433-9941

** Yükseklisans Öğrencisi, Eskişehir Osmangazi Üniversitesi, SBE, onursy@gmail.com, ORCID: 0000-00023143-0404
}

Date of Arrival: 29.05.2021 - Date of Acceptance: 28.06.2021. 


\section{Giriş}

Hegemonya, uluslararası sistemi şekillendirme gücüne sahip olan bir aktörün bu yeteneğini ifade etmektedir. ${ }^{1}$ Hegemonya kavramı, baskın gücün nasıl oluşturulduğunu, sürdürüldüğünü ve bu güce yönelik meydan okumaları; küresel gücün inşasını ve küresel ilişkilerin karakteristiğini anlamak için temel kavramlardan birisidir. Hegemon devlet, baskın güç ve liderlik uygulamalarıyla tanımlanır, ancak uluslararası arenada devlet dışı aktörlerin önemi arttığından artık hegemonya yalnızca bir devlet tarafından sahiplenilememektedir. Hegemon devlet, doğrudan toprak istilası yerine rızayı esas alarak başkalarının isteklerini değiştirme yeteneği olarak anılan, yumuşak güç sayesinde diğer devletlerin karar alma mekanizmalarını kendi çıkarları doğrultusunda etki altına alma yoluna gitmekte, amaçlarına ulaşamaması halindeyse zor kullanarak istediği sonuçları elde etme yöntemi olan sert güçten faydalanmaktadır. Hegemon devlet, en büyük askeri güce sahip, en önemli ekonomik ve diplomatik aktör olarak, uluslararası siyasete liderlik etme yeteneğine sahiptir. ${ }^{2}$

Hegemonya, genellikle 19. yüzyıl Büyük Britanya'sı veya Soğuk Savaş sonrası ABD’si gibi tek bir devletle anılsa da, Avrupa Birliği (AB) gibi karar alma yetisine sahip siyasi bir topluluğu da ifade edebilmektedir. ${ }^{3}$ Hegemon devlet, uluslararası piyasadaki gücüyle malların fiyatlarını manipüle ederek o devletlerdeki siyasi aktörlerin politik tercihlerini etkileme yoluna gidebilir, ya da diğer devletlerin kamuoyu ve siyasal gündemini, kendi çıkarları doğrultusunda etkilemek için propaganda yöntemleri seçerek yaptırımlar uygulayabilir. ${ }^{4}$

Soğuk Savaş öncesinde hegemonya kavramı, asimetrik güç ilişkilerini ifade etmekteydi. Günümüzdeyse, kültürel hegemonyadan küresel hegemonyaya kadar pek çok alanda kullanılmaktadır. Bilimsel çalışmaların çoğu Amerikan hegemonyasına odaklansa da ABD hegemonyasının gerilediğini, hatta en büyük rakibi olan Çin'in gelecekte üstün konuma geleceğini savunan çalışmalar da mevcuttur.

İkinci Dünya Savaşı sonrasında İngiltere'nin hegemonyasının sona ermesinin ardından hegemon ülke konumuna ulaşan ABD, uluslararası normları kendi çıkarlarına uygun şekilde

\footnotetext{
${ }^{1}$ Carla Norrlof, "Hegemony" (Oxford University Press, 2015).

${ }^{2}$ Immanuel Maurice Wallerstein, The Politics of the World-Economy (Cambridge: Cambridge University Press, 1984), 38.

${ }^{3}$ Norrlof, "Hegemony".

${ }^{4}$ Lake David, "Britanya ve Amerikan Hegemonyasının Karşılaştırılması: Gerileme Çağı Üzerine Bazı Dersler”, Çev. Mehmet Zeki Ak ve Ünsal Ozan Kahraman, Bilgi 28, (2014): 131.
} 
IJPS, 2021: 3(3):332-368

International Journal of Politics and Security, 2021: 3(3):332-368

değiştirebilme gücüne ulaşmıştır. Askeri ve ekonomik faktörlerin dışında Açık Kader (Manifest Destiny) olarak bilinen ve ABD’nin Tanrı tarafından bahşedilmiş mevcut kıtadaki doğal yayılma hakkının alınmaya çalışılmasının Tanrı'ya karşı gelmek anlamına geldiğine yönelik inanç, Amerikan hegemonyasının inançsal zeminini oluşturmuştur. Bu doğrultuda Amerikan halkı farklı ve "seçilmiş” olduklarına inanmaktadır. ${ }^{5}$ Bu bağlamda, ABD’nin kuruluşundan itibaren ön planda olan kişisel özgürlükler, kapitalizm gibi kavramlar hem Amerikan politik kültürünün temel unsurları olmuş hem de dünyanın geri kalanı tarafından benimsenmesi gereken kavramlar olarak ifade edilmiştir.

ABD'nin tek hegemon güç olmasında şüphesiz SSCB'nin çöküşü en önemli neden olmuştur. Bu çöküşe giden süreçte, ABD'nin 1980'lerde silahlanmaya ağırlık vererek SSCB'yi silahlanma yarışının içine sokması; oldukça artan savunma harcamaları yüzünden, SSCB ekonomisinin çöküşü Soğuk Savaş’ın sonunu getirmiştir. SSCB, Batı ile ekonomik açmaza düşmüş, sonuç olarak çöküşü kaçınılmaz olmuştur. Bu çöküşte ekonomik gerekçelerin yanı sıra elitlerin ve üst düzey yöneticilerin yaklaşımları, keyfi tercihleri de rol oynamıştır. SSCB'nin desteklediği kurum ve altyapıların da dağılmasıyla ABD rakipsiz kalmıştır.

$\mathrm{Bu}$ çalışmada SSCB dönemi sonrasında daha çok neo-revizyonist bir yaklaşımı benimseyen ulusal çıkarları ve prestiji kabul edildiği sürece Amerikan hegemonyasını kabul eden Rusya'dan çok, ABD'nin hegemonik rekabetteki en büyük rakibi olan Çin'le mevcut şartlardaki ve gelecekteki hegemonyasının seyri ele alınmıştır. Çünkü potansiyel hegemon bir devlet, süper güç olma yolunda kendisine katılacak ittifakları ve kendi uluslararası sisteminde uyulması gereken temel unsurları belirtilmelidir. SSCB sonrasında indirgenmiş statüsü ile Rusya bu kapsamda ele alınmamıştır.

Bu doğrultuda, çalışma kapsamında Amerikan hegemonyasının rekabet süreci, özellikle günümüz koşullarına ağırlık verecek şekilde ele alınmış olup, hegemonyanın gelecekteki görünümüne dair öngörülere de yer verilmeye çalışılmıştır.

\footnotetext{
${ }^{5}$ Gültekin Sümer, “Amerikan Dış Politikasının Kökenleri ve Amerikan Dış Politik Kültürü”, Uluslararası İlişkiler Dergisi 5, no. 19 (2008): 123.
} 


\section{Hegemonya Kavramı ve Amerikan Hegemonyasının Kısa Tarihi}

\subsection{Hegemonya: Kavramsal, Tarihsel ve Teorik Arka Plan}

Dünya hegemonyası, öncesinde sosyal bir sınıf tarafindan kurulup güçlendirilmekte, sonrasında genişleyerek ulusal egemenlik sınırlarını ihlal ederek diğer tüm ülkelerin üretim tarzlarını etki alanına almaktadır. Hegemon devletin sadece diğer devletleri değil, sivil toplum kuruluşlarını da etki altına alarak kendi ideolojisini evrenselleştirmesi ve kendi dünya düzenini koruması gerekmektedir. Bir hegemonun asıl amacı, kendi bölgesinde hegemonyasını kurarken, rakip büyük devletin başka bir bölgede tahakküm oluşturmasını önlemektir. ${ }^{6} \mathrm{Bu}$ sebeple kendisine tabi olan ülkelere finansal, sosyal ve politik örgütlenme modellerinin yanı sıra, kendi kültürünü ve teknolojisini de empoze etmelidir. Buna rağmen, merkezdeki hegemon devlette yerleşik haldeki bu modellemeler, çevre ülkelerde tam olarak benimsenemeyebilir, bu durum da hegemonya açısından çelişkiler oluşturur.

Tarih boyunca, Amerikan hegemonyası iki kez yükselişe geçmiştir. Bunların ilki, Birinci Dünya Savaşı'nın hemen ardından, diğeri ise Soğuk Savaş'ın sonunda olmuştur. ${ }^{7}$ Woodrow Wilson'ın ulusların kendi kaderlerini tayin hakkı ilkelerini tanımlaması, ideolojik ve ekonomik açıdan cazip olan bu güçlü devletin dünya sahnesindeki yerini almasının bir işareti olmuştur. Kurulduğu dönemden itibaren uzun yıllar boyunca kendisini soyutlayan, içe dönük politika izlemiş olan ABD, Birinci Dünya Savaşı ile adını uluslararası alanda duyurmaya başlamıştır. Bu dönemde canlı ekonomik ve sosyal yapısıyla stratejik bilince sahip ABD’nin hegemonik liderliğine duyulan ihtiyaç dünyaya hâkimdi. İkinci Dünya Savaşı'ndan beri onlarca yıldır Avrupa ve Asya ülkeleri, ulusal güvenliklerini korumak adına ABD şemsiyesine güvenmektedir. Bu ülkeler, ABD’nin ekonomik politikaları kapsamında küresel pazara erişim sahibi ülkeler olarak ekonomik refaha da ulaşmıştır. ${ }^{8}$

1917 ve 1989 yılları arasında süregelen "küresel iç savaş”, Soğuk Savaş sonrası dönemde ortaya çıkan evrenselcilik ve çoğulculuk arasındaki gerilimi tıkamıştır. Böylece, önceden düzenlenmiş hegemonya biçimi olan Anglo-Amerikan hegemonya, fark ettirmeden

\footnotetext{
${ }^{6}$ John J. Mearsheimer, The Tragedy of Great Power Politics (New York: Norton Press, 2001), 1.

${ }^{7}$ Soğuk Savaş sonrası düzen üzerine geniş bir çalışma için bkz. Kantarcı, Ş . "Soğuk Savaş Sonrası Uluslararası Sistem: Yeni Sürecin Ad1 “Koalisyonlar Dönemi mi?”". Güvenlik Stratejileri Dergisi 8, (2012 ): 47-84.

8 Jamie Metzl, "Trump and Global Security", Central Tibetan Administration, 05 Nisan 2017 , https://tibet.net/trump-and-global-security/ (31.10.2020).
} 
gerçek sorunları çarpıtarak yeni bir “enternasyonel” düzen oluşturmuştur. ${ }^{9}$ Eisenstadt'ın terimiyle, "modernite uygarlığı" ile alternatif ilişki biçimleri ortaya dökülmüştür. ${ }^{10} \mathrm{SSCB}$, Soğuk Savaş döneminde mevcut hegemonyasının meşruiyetini pekiştirmek amacıyla, 1956'da Macaristan'a ve 1968'de Çekoslovakya'ya yaptığı gibi kendi koalisyonunda rızanın zayıfladığı yerlere askeri güç kullanmıştır. ${ }^{11} \mathrm{Bu}$ bağlamda SSCB, hegemonik bir güce sahipken, dış politikasını uydu devletleri üzerinde emperyal hâkimiyetle temellendirmiştir. Ayrıca askeri gücün ötesinde ekonomik, siyasi ve yumuşak güç unsurlarına hâkim olan ülkelerin hegemon olduğu yeni dünya düzenindeki yapısal değişikliklere SSCB, ABD gibi uyum sağlayamamıştır. Bununla birlikte, Soğuk Savaş sonrasında tek hâkim güç haline gelen Amerikan hegemonyasının tıpkı 17. yüzyıldaki İspanya, 18. yüzyıldaki Fransa, 19. ve 20. yüzyılın başlarındaki İngiltere örneklerindeki gibi, uluslararası ekonomik sisteme bağlı devletlerin sisteme inançlarını kaybederek kopmaları ve sistemin dağılmasıyla sona erebileceği düşünülmektedir.

20. yüzyılda ABD salt askeri unsurlarla yetinmemiş, kültürel ve siyasal değerlerine dayanan yumuşak unsurları da başarıyla kullanarak, Birinci Dünya Savaşı sonunda Milletler Cemiyeti, İkinci Dünya Savaşı sonunda ise Birleşmiş Milletler (BM) gibi uluslararası kuruluşlarla Bretton-Woods gibi uluslararası ekonomik yapılanmaların kurulmasına öncülük etmiştir. İkinci Dünya Savaşı sonrasında "ekonomik durgunluk” beklenirken, süreçten 'savaş ekonomisi' sayesinde güçlenerek çıkan ABD’nin, Avrupa ve Japonya ekonomilerini adeta yeniden inşa etmesiyle oluşan Bretton Woods süreciyle ABD, hegemonyasını ve para biriminin küresel baskınlığını kabul ettirirken, oldukça kurumsallaşmış çok taraflı bir sistemin temellerini atmıştır. ${ }^{12}$ Bu doğrultuda, Amerikan hegemonyası, liberal değerlerin Batı Avrupa ve Üçüncü Dünya Ülkeleri elitleri tarafından benimsendiği, benimsemeyen ülkelerinse "karşı kamp" olarak etkin bir biçimde çevrelendiği 1945'ten sonraki süreçte kurulmuştur (Çiftçi, 2009: 207). İkinci Dünya Savaşı sonrasında kurulan BM, Kuzey Atlantik Antlaşması Örgütü (NATO), Gümrük Tarifeleri ve Ticaret Genel Antlaşması (GATT), Uluslararası Para Fonu (IMF) vb. uluslararası örgütler, bu Yeni Dünya Düzeninin kurulmasını ve benimsenmesini sağlamıştır.

\footnotetext{
${ }^{9}$ Chantal Mouffe, On the Political (London\&New York: Routledge Press, 2005), 7.

${ }^{10}$ Shmuel N. Eisenstadt, "The Civilizational Dimension of Modernity: Modernity as a Distinct Civilization", International Sociology 16, no. 3 (01 Eylül 2001): 325.

${ }^{11}$ Michael Hardt ve Antonio Negri, Empire (Cambridge, Mass: Harvard University Press, 2000), 92.

12 John Bellamy Foster, “The End of Rational Capitalism”, Monthly Review 56, no. 10 (01 Mart 2005): 5.
} 
Liberal düzenin temelindeki ekonomi ile birlikte bir diğer unsur, çok taraflı müttefik kurumlardır. Günümüzdeyse artan sivil oluşumlar, ABD’nin güdümünde olmayan kurumlar, BM'nin tek başına hüküm sürmesini engelleyerek, liberal düzenin düşüşünde rol oynamaktadır.

Soğuk Savaş sonrasında ABD, kendi uygun gördüğü liberal çerçevede özgür dünya ekonomisini yaratıp, küresel ticaretin ve finansmanın önünü açarak, güvenlik açığını karşılarken, buna karşılık oluşturmayı hedeflediği hegemonyasına karşı olan özgür olmayan dünyaya (geçmişte SSCB, şimdilerde Çin) karşı, müttefiki olan ülkelerden kendisiyle dayanışma içerisinde olmalarını istemiştir. Daha açık ve serbest dünya ekonomisi, ABD yönetiminin kendisine hizmet eden eylem planlarına dayanmaktadır. ABD'nin zengin ekonomik kaynaklarının yanı sıra, ideolojik olarak da liberalizmle desteklenen hegemonyası, İkinci Dünya Savaşı sonrasında, kurumsal etkinliklerden de güç bulmuştur. Bu kapsamdaki Marshall Planı, Avrupa'da kademeli olarak, 1946'da öngörülen açık ekonominin uygulanabilmesi amaciyla ticaretin serbestleştirilmesine ve döviz konvertibilitesine olanak sağlamıştır. ${ }^{13}$

Amerikan hegemonyası, temel olarak askeri güç üstünlügünün sürdürülmesi, liberal ekonomik sistemin küresel hâkimiyetinin korunması ve genişletilmesiyle küresel kurumsal yapının korunması ve revize edilmesine dayanmaktadır; ancak, Amerikan hegemonyasını açıklamakta sadece bu üç etkenle yetinmek eksik kalabilir. Hegemonyayı açıklarken, hegemon devletin para biriminin uluslararası geçerliliğinin olması, dünyadaki kilit noktalarda üsler bulundurması ve müttefiklere sahip olması, dünyanın farklı bölgelerindeki bölgesel kriz ve çatışmaların çözümlerine öncülük etmesi, belirgin nükleer güce sahip olması, diğer ülkeler üzerinde ikna gücü ve tahakkümünün bulunması ve kendi kültürünü 'evrensel' hale getirip, diğer devletlere empoze etmesi ve meşrulaştırması gibi bölgeselliği aşan, yapısal güç gerektiren durumlar önemlidir. ${ }^{14}$ ABD üslerinin Amerikan değerlerini, ABD’nin serbest piyasa anlayışını ve hâkimiyetini o bölgeye empoze etme amaçları taşıdığı iddia edilse de, Soğuk Savaş sonrasında bu üslerin ABD için önemi ve ABD'nin ulaştığı teknolojik seviye itibarıyla bu üslere ihtiyacı tartışma konusu olmuştur. ${ }^{15}$

\footnotetext{
${ }^{13}$ Robert W. Cox, Production, Power, and World Order: Social Forces in the Making of History (Columbia University Press, 1987), 215.

14 Zbigniew Brzezinski, Büyük Satranç Tahtası: Amerika'nın Küresel Üstünlüğü ve Bunun Jeostratejik Gereklilikleri, çev. Y. Türedi (Ankara: İnk1lap Kitabevi, 2010), 39, 87.

${ }^{15}$ Selin M. Bölme, Incirlik Üssü: ABD’nin Üs Politikası ve Türkiye (İstanbul: İletişim Yayınları, 2012), 53-58.
} 
ABD süper güç olarak hegemon çıkarlarının yanı sıra küresel düzen ve refahı da geliştirecek şekilde hareket etmiştir. Bu yeni sistemle ABD hem düzen koruyucu role bürünmüş hem de politik, ekonomik ve sosyal açılardan kendi politikalarının uluslararası örgütlere göre düzenlenmesini sağlamıştır. Bu noktada aslında ABD’nin uygulamaya koyduğu şey, 19. yüzyılda kurmuş olduğu sistemi (liberal, özgürlükçü, eşit eyalet sistemi) küreselleştirmektir.

ABD hegemonyası, her ne kadar Soğuk Savaş'tan itibaren kabul gören bir kavram olsa da, ABD’nin bir imparatorluk olduğu iddiası, 11 Eylül saldırılarından sonra alevlenmiştir. Dönemin ABD devlet başkanı George W. Bush, ABD’nin imparatorluk amacı taşımadığını ve ulusunun kendi özgürlüğüne ve başkalarının özgürlüğüne bağlı olduğunu ifade etmiştir. ${ }^{16} \mathrm{Bu}$ doğrultuda, başta John Ikenberry olmak üzere, Daniel Deudney, Andrew Hurrel ve John Agnew gibi bilim adamlarının ABD’nin daha az müdahaleci bir dış politikaya sahip olması nedeniyle imparatorluk savına muhalefet ederek, daha çok hegemonik güç olarak tanımlanması gerektiğini iddia etmişlerdir. ${ }^{17}$

Özellikle ABD’nin 11 Eylül sonrasında Irak’ı işgali, ABD imparatorluğunun, Roma İmparatorluğu'nun bir tekrarı olduğu algısını oluşturmuştur. Bununla birlikte, 11 Eylül öncesi "İmparatorluk" iddiasını savunan bazı araştırmacılar, "ABD imparatorluğunun, Roma İmparatorluğu ve kapitalist emperyalizmin aksine, yeni ve ilerici bir egemenlik anlayışına sahip olduğunu ifade etmişlerdir. Amerikan imparatorluğu, emperyalizmin aksine bölgesel güç merkezine sahip değildir, bunun yerine önemli bir rol oynadığı ancak tam anlamıyla hâkim olamadığı ağlar aracılığıyla dünyayı yönetmektedir. Bunun yanı sıra imparatorluğun egemenliği, belirli sınırlara ve engellere dayanmamaktadır. Bush’un “şeytan ekseni” olarak ötekileştirdiği ülkeler de ${ }^{18}$ dâhil olmak üzere tüm dünya imparatorluğa aittir. ${ }^{19} \mathrm{Bu}$ dönemde Afganistan'ın ötesindeki tehlikeli rejimleri devirmek için "düşük dereceli sömürgecilik" çağnıs1 ${ }^{20}$ gibi ifadelerin kullanılmaya başlandığı Kasım 2002-Nisan 2003 döneminde

\footnotetext{
${ }^{16}$ George W. Bush, "Remarks at a White House Reception for Veterans" (The White House, 11 Kasim 2002), https://www.presidency.ucsb.edu/documents/remarks-white-house-reception-for-veterans (20.09.2020).

${ }^{17}$ Charles Philippe David ve David Grondin, ed., Hegemony or empire? the redefinition of US power under George W. Bush (Aldershot, England ; Burlington, VT: Ashgate, 2006), 2.

${ }^{18}$ George W. Bush, "President Delivers State of the Union Address" (The United States Capitol, 29 Ocak 2002), https://georgewbush-whitehouse.archives.gov/news/releases/2002/01/20020129-11.html (20.09.2020).

19 Hardt ve Negri, Empire, xii.

${ }^{20}$ Nina J. Easton, "Thunder on the Right", American Journalism Review 23, no. 10 (2001): 320.
} 
yayınlanan haberlerde "Amerikan imparatorluğu" terimi binden fazla kez vurgulanmıştır. ${ }^{21}$ Amerikan imparatorluğundan beklenen, Roma prokonsüllerinin (eyalet valisi) yaptığı gibi anarşist yapıdaki dünyaya kanun ve nizam getirmesiydi. ${ }^{22} \mathrm{ABD}$, bu doğrultuda aşırı nüfuz sahibi olduğu sorumluluğu altındaki yarı özerk nitelikteki devletleri Roma İmparatorluğu'nun prokonsüllerinin günümüz eşdeğeri olarak tanımlanabilecek merkez üsleri haline getirmiştir. ${ }^{23}$ $\mathrm{Bu}$ yöntem, Roma İmparatorluğu'nun devletler üzerinde doğrudan ilhak etmek yerine, kendisine yandaş ve dost rejimler oluşturma yöntemine benzemektedir.

Berlin Duvarı'nın yıkılmasının SSCB'nin sonunu getirdiği gibi, 2008 Küresel Ekonomik Krizi'nin de ABD’nin sonunu getireceği iddia edilmiştir. Bu kriz, öncekilerden çok daha yıkıcı görülmüş, güç dengelerinin sonsuza dek değişeceği gündeme gelmiştir. ${ }^{24} \mathrm{Bu}$ senaryoya göre, dünya yeni bir "yumuşak dengelenme" olgusuna tanık olmaktadır, böylece devletler, ABD'nin hegemonyasına direnmekte ve karşı eylemler yürütmeye çalışmaktadır. Geleneksel dengeleme politikasına alternatif olarak sunulan yumuşak dengelemedeki amaç, ABD’nin gücüne meydan okuma yoluyla girişilecek yüksek maliyetli eylemler yerine ekonomik kaldıraçlar ve BM gibi uluslararası kurumlarda diplomatik manevralar uygulanması, ABD üslerine karşı direniş ve ABD’nin askeri müdahalelerine muhalif olma gibi yöntemler izleyerek, ABD gücünü zayıflatmak ve sınırlandırmaktır. ${ }^{25}$

Hegemonyayla ilgili tarihsel süreçte en önemli sorulardan biri de hegemonya sonrasında dünyanın nasıl şekilleneceği ve baskın gücün yokluğunda uluslararası işbirliğinin nasıl oluşturulacağıyla ilgili olmuştu. ${ }^{26}$ Günümüzde devletlerin birçoğunun Çin'le ticaret ortaklıklarıyla, ABD’nin güvenlik şemsiyesi arasında kalıp, bu ikileme rağmen ikisine birden sahip olmak istediği bilinmektedir. Bununla birlikte, ABD ve Çin de hegemonik rekabette geride kalma endişeleriyle dünyayı kendi çıkarlarına uygun şekilde yeniden şekillendirebilmek

\footnotetext{
${ }^{21}$ David A. Lake, "Escape from the State of Nature: Authority and Hierarchy in World Politics", International Security 32, no. 1 (2007): 48.

${ }^{22}$ Günter Bischof, “Empire Discourses: The »American Empire« in Decline?”, Kurswechsel, 2009, 18.

${ }^{23}$ Andrew Feickert, "The Unified Command Plan and Combatant Commands: Background and Issues for Congress" (Congressional Research Service, 03 Ocak 2013), 59, https:/fas.org/sgp/crs/natsec/R42077.pdf.

${ }^{24}$ John Gray, “John Gray: A Shattering Moment in America's Fall from Power”, The Guardian, 27 Eylül 2008, blm. Opinion, http://www.theguardian.com/commentisfree/2008/sep/28/usforeignpolicy.useconomicgrowth (15.04.2019).

${ }^{25}$ Keir A Lieber ve Gerard Alexander, "Waiting for Balancing: Why the World Is Not Pushing Back", International Security 30, no. 1 (Temmuz 2005): 109, 125.

${ }^{26}$ Robert Owen Keohane, After Hegemony: Cooperation and Discord in the World Political Economy (Princeton: Princeton University Press, 1984), 9.
} 
adına bu devletlerin üzerinde yaptırım tehditleri dâhil her kozu oynamaktadır. ${ }^{27} 21$. yüzyılın başından itibaren iyice belirginleşen kutupsuz hegemonya anlayışına göre, ABD'nin hegemonyasını sürdürememe ve küresel ilişkileri kontrol etmesini sağlayan hegemonyasını yeni hegemona aktaramama ihtimali söz konusudur. Üstelik bu durum, potansiyel hegemon devletin çabalarıyla değil; küreselleşme sürecinin yayılımıyla özellikle Asya, Afrika ve Latin Amerika'daki gelişmekte olan ülkelerin barış ve kalkınma dürtüsü ${ }^{28}$, hegemon devletin etkisini azaltan iklim değişikliği ve salgın hastalıklar -Covid 19- gibi unsurlar ile dünyada çok sayıda merkezden yönetilen hegemonsuz yeni bir siyasi yapı oluşabilir. Hegemonyasız uluslararası sistem anlayışının küresel hegemonya ve egemenliği devletlerin doğal bir eğilimi olmadığı savunulurken, sürdürülebilir barışın, savaşın ve hegemonyanın yokluğu sayesinde olacağı öne sürülmüştür. ${ }^{29}$ Ancak hegemonyasız dünyada acil küresel ve bölgesel sorunlara tepki vermek, karar vericilerin fazlalığı nedeniyle zorlaşacaktır, bu durum, terör örgütlerinin sayısı ve etkisinin artmasına neden olabilir. Bu durumda, ticari ve ekonomik ilişkilere bağlı karşılıklı bağımlılıklar, hegemonyasız düzende küresel güvenliğin sağlanmasında etkili olabilir.

\section{Amerikan Hegemonyasının 21. Yüzyıldaki Durumu}

Soğuk Savaş'ın sona ermesinden sonra AB, Japonya, Rusya, Çin ve Hindistan, ABD’ye giderek daha fazla meydan okumaya başlamıştır. Soğuk Savaş'ın bitiminden sadece yirmi yıl sonra, ABD’nin küresel konumunun zayıflamasıyla AB'nin siyasi anlamda ciddi bir küresel oyuncu olarak ortaya çıkacağını, Amerikan hegemonyasına bir anlamda rakip olabileceğini çok az kişi öngörebilmiştir. 11 Eylül sonrasındaki süreçte, ABD’ye karşı dünyanın tavrı (Orta Doğu, Latin Amerika, Afrika) düşmanca olmuştur. İkinci ABD-Irak Savaşı sonrasında Irak'ta devam eden şiddet ve istikrarsızlık, geniş ve derin seviyedeki anti-Amerikancılık, ABD'nin seçeneklerini, seçimlerini ve yeteneklerini sınırlamaya yönelik rakip güçlerin yükselişi, bu düşmanca tavrı derinleştirmektedir. ${ }^{30}$

27 Uri Friedman, "How to Choose Between the U.S. and China?", It's Not That Easy", 2019, https://www.theatlantic.com/politics/archive/2019/07/south-korea-china-united-states-dilemma/594850/.

${ }^{28}$ Chen Xiankui ve Tang Wei, "Coming collapse of the hegemonic world", China Daily, 12 Eylül 2008, http://www.chinadaily.com.cn/opinion/2008-09/12/content_7021668.htm (21.12.2020).

29 Amitav Acharya, "Nonhegemonic international relations: A preliminary conceptualization", Centre for Governance and International Affairs University of Bristol, Working Paper (2008): 4.

${ }^{30}$ Michael Cox, "Is the United States in Decline-Again? An Essay", International Affairs 83, sy 4 (Temmuz 2007): 651 . 


\subsection{Amerikan Hegemonyasının Soğuk Savaş Sonrasındaki Doğası}

Washington yönetimi, Birinci ABD-Irak Savaşı sırasında Yeni Dünya Düzenini ilan etmiştir. Sonrasında SSCB'nin dağılmasının ardından ABD'nin kontrolünde yeni hegemonik düzen kurulmuştur. Yeni Dünya Düzeni, uluslararası ve bölgesel organizasyonlarla danışma, işbirliği ve ortak harekete dayanan ve demokrasi, refah ve barışın yaygınlaşmasını ve silahların azaltılmasını hedefleyen bir ortaklık olarak tanımlanmıştır. ${ }^{31}$ ABD Başkan’ı George H. W. Bush'un 1991'de BM'de yaptığı konuşmayla Soğuk Savaş sonrasında ABD liderliğinde küresel barışın teminini hedeflenmiştir. Bu hedef, aynı zamanda ABD’nin küresel genişleme stratejisinin temelini oluşturmuştur. Ancak süreç, ABD’nin istediği gibi ilerlememiş ve 11 Eylül 2001 saldırısı, uluslararası sistem için bir dönüm noktası olmuştur. ABD, 1989'da Berlin Duvarı'nın yıkılışından 2001'deki saldırıya kadar geçen süreçte ulusal güvenliği adına artık mevcut sınırlarının ötesine bakması gerektiğini anlamıştır. ${ }^{32}$

Soğuk Savaş'ın sona ermesiyle küresel hegemonik gücünü kaybeden Rusya, bölgesel hegemon olarak Kuzeydoğu Asya'da ABD ve Çin'le rekabet halindedir. Özellikle Çin'in Rusya ve Çin arasında denge politikası içindeki Kuzey Kore ile olan kapsamlı, sistematik ve gizli ekonomik programı, Rusya’yı tedirgin etmektedir. Bunun yanı sıra Rusya, ABD-Çin arasındaki rekabete bağlı gerilimi hafifleten bir güvenlik ağı sağlayan stratejik bir aktör olmasına rağmen ${ }^{33}$, günümüzde dünya ekonomisinin yalnızca yüzde 2'sine denk gelen 1,7 trilyon dolarlık milli geliriyle ekonomik anlamda küresel hegemon olabilmekten hayli uzaktır. ${ }^{34}$ Ayrıca Rusya'nın büyük ölçüde enerji ihracatına bağımlı olan ekonomisinde yüksek teknoloji ürünlerinin ihracattaki payı, yalnızca yüzde 11'dir (ABD için bu oran yüzde 19). ${ }^{35}$ Ek olarak, Rusya, tarihsel ve kültürel bağlarıyla etrafındaki ülkelerde kısmen yumuşak güce sahip olsa da kültürünü dünyaya yeterince kabul ettirememiştir. Rusya bilimde de geride kalmaktadır; dünyada 2021 yılı için belirlenen en iyi üniversiteler sıralamasında ilk yüz içerisinde sadece bir

31 George H.W. Bush, “Address Before United Nations General Assembly”, 1990, http://dosfan.lib.uic.edu/ERC/briefing/dispatch/1990/html/Dispatchv1no06.html/ (17.04.2019).

${ }^{32}$ Ahmet Davutoğlu, "Felsefi ve Stratejik Boyutlarıyla 11 Eylül Sonrası Dönem", içinde Sahibini Arayan Barış, ed. B. Masis Kürkçügil (Istanbul: Everest, 2002), 56.

${ }^{33}$ Beom Shik Shin, "Russia's Place in the Changing Strategic Triangle in the Post-Cold War Northeast Asia: From an Outcast to a Strategic Player?", The Journal of International and Area Studies 22, sy 2 (2015): 121-28.

34 The World Bank, "World Bank in Russia - Overview", Text/HTML, World Bank, (2020), https://www.worldbank.org/en/country/russia/overview (17.11.2020).

35 The World Bank, "High-technology exports (\% of manufactured exports)", 2019, https://data.worldbank.org/indicator/TX.VAL.TECH.MF.ZS?\%20locations=US-RU (17.11.2020). 
üniversiteye sahiptir. ${ }^{36}$ SSCB dönemindeki gibi NATO ve benzeri uluslararası sisteme ait kendi kurumlarının olmaması, etkili piyasa ekonomisi için kurumsallaşma eksikliği, nüfus azalması gibi ciddi demografik yapısal sorunlara sahip olması ve tek ürün ekonomisi olarak adlandırılabilecek enerjiye bağımlı ekonomik yapısıyla Rusya, defansif bir süper güç ve güçlü bir bölgesel hegemon olmasına rağmen, ABD’nin hegemonyasıyla küresel ölçekte rekabet edememektedir. Ancak sahip olduğu muazzam nükleer gücü, doğal kaynakları, siber teknoloji gücü ve ABD’ye karşı Soğuk Savaş dönemindeki gibi Çin'le ittifak yapma olasılı̆̆g gibi nedenlerle Rusya, ABD ve Avrupa için büyük tehditlerden biri olmaya devam etmektedir. ${ }^{37}$ Rusya'nın talep ettiği koşulların AB'nin entegrasyon ilkeleri gereği eşitlik ilkesine uymaması nedeniyle, AB ile arasındaki stratejik ve bütüncül ortaklık fikri 2000'lerin ortalarından itibaren aşınmaya başlamıştır. Bu durumun asıl sebebi, Rusya'nın iç ve dış politikasının önemli ölçüde değişmesi ve AB’nin 2010'ların başından itibaren Rusya'nın izlediği politika sonucunda kendisine yakın coğrafyalarda birbiri ardına yaşanan siyasi sorunların ardından güçlenen mülteci kriziyle yüzleşmiş olmasıdır. ${ }^{38}$ Rusya, mevcut düzende jeopolitik ve ekonomik çıkarlarını güvence altında tutmaya ve kendi siyasal düzeniyle SSCB dönemindeki küresel gücünü yeniden elde etmeye çalışan, yükselen bir güç konumundadır. Fakat hem demokratik olmayan yönetim anlayışıyla Batı'nın demokratik fikirlerinin nüfuzuna karşı etkisiz durumda olduğundan, Batı'nın değerlerine evrensel anlamda meydan okuyamamakta hem de ideolojisiyle, kendi etki alanındaki ülkeler haricinde çok az bir cazibeye sahiptir. ${ }^{39}$ Çin ise Soğuk Savaş sonrası dönemde, hızlı ekonomik liberalleşmesini, pek değişmeyen otoriter siyasi sistemiyle birleştirerek, kendi piyasa anlayışını yansıtan devlet kontrollü otoriter kapitalist sistemi kabul etmiştir. ${ }^{40}$ Nisan 1997'de Çin Devlet Başkanı Jiang Zemin ve Rusya Devlet Başkanı Boris Yeltsin'in küresel çok kutupluluk ve yeni bir uluslararası sistem kurulması vaadi sonrasında pek çok Batılı politika yapıcı, bu meydan okumayı ciddiye almamıştır ve özellikle

\footnotetext{
36 “QS World University Rankings 2021”, Top Universities, 2020, https://www.topuniversities.com/universityrankings/world-university-rankings/2021 (13.11.2020).

${ }^{37}$ Joseph S. Nye, "How to Deal with a Declining Russia", Project Syndicate, 05 Kasım 2019, https://www.projectsyndicate.org/commentary/dealing-with-danger-of-declining-russia-by-joseph-s-nye-2019-11 (17.11.2020).

${ }^{38}$ Fyodor Lukyanov, "Is Russia's Dialogue with the EU Coming to an End?", The Moscow Times, 15 Ekim 2020, blm. Opinion, https://www.themoscowtimes.com/2020/10/15/is-russias-dialogue-with-the-eu-coming-to-an-enda71766 (12.12.2020).

${ }^{39}$ Francis Fukuyama, "History Is Still Going Our Way", Wall Street Journal, 05 Ekim 2001, blm. Front Section, https://www.wsj.com/articles/SB1002238464542684520 (12.07.2020).

${ }^{40}$ Ronald H. Coase ve Ning Wang, "How China Became Capitalist", Policy Report (CATO Institute, 15 Ocak 2013), https://www.cato.org/policy-report/january/february-2013/how-china-became-capitalist (12.07.2020).
} 
Çin'in ABD'nin uluslararası sistem ve normlarına sadık kalarak sistemden faydalandığını öne sürmüşlerdir. Bununla birlikte Çin, küresel ticarette 4,3 trilyon dolarla yaklaşık yüzde 10 payla devasa ticaret hacmine sahip olması ve kendine has ürünler pazarlamasına istinaden diğer devletlerin anti-damping önlemlerine yoğun şekilde maruz kalması nedeniyle, Aralık 2001 'de Dünya Ticaret Örgütü'ne (DTÖ) üye olmuştur. Bu durum, dünyada küresel politika ve güç dengelerinde değişime işaret olurken, aynı zamanda Çin'in güç ve ideoloji temelli küresel davranışı, yerini ABD uluslararası neo-liberal sistemin bir unsuru olan DTÖ’nün büyük ölçüde kabul görmüș kurallarına bırakmıștır. ${ }^{41}$

Bugün, Çin ve Rusya gibi liberal olmayan ve otokratik devletler, ABD liderliğindeki neo-liberal uluslararası sisteme kısmen rakip olmuş; tarihsel olarak ABD ve müttefiklerinin hâkim olduğu bölgelere girmektedirler. Çin, örneğin, 17+1 grubuyla Orta ve Doğu Avrupa devletleriyle irtibat halindedir ve Çin-CELAC Forumu ile Latin Amerika ülkelerinde etkili olmaktadır. ${ }^{42}$ Hegemonik rekabette Çin, sistematik bir rakip olarak, geleneksel Batı bloklarının uyumuna meydan okuyarak Amerikan hegemonyasını sorgulanır hale getirmiştir. Amerikan hegemonyasına meydan okumasının temel dayanağı, Çin'in ABD'nin kendi neo-liberal ideolojisine uyumlu dünya anlayışına alternatif olarak görülen politik-ekonomik sistemidir. Ancak her ne kadar ekonomik küreselleşmeyi destekleseler de, çok kutuplu bir dünyayı savunan Çin ve Rusya gibi Batılı olmayan devletlerin aktif devlet müdahalesi gibi liberal olmayan yönetişim modellerini ön plana çıkarmaları, uluslararası sistemin en önemli unsurları olan serbest piyasa ekonomisi ve liberal demokrasiyi zayıflatabilir. ${ }^{43}$

Trump'ın ABD’nin yönetim anlayışında yaptığı popülist değişiklik sonrasında, birçok yorumcu tarafından özgür dünya lideri olarak Almanya gösterilse de Merkel bunu kesin olarak reddetmiştir. ${ }^{44}$ Zaten dünyanın en büyük askeri gücüne sahip $\mathrm{ABD}$, jeopolitik süper güç statüsünü koruma adına, kendisine kıyasla uluslararası prestijden yoksun, nükleer gücü olmayan ve zayıf askeri güce sahip olan Almanya'ya özgür dünyanın liderliğini

\footnotetext{
41 "WTO successfully concludes negotiations on China's entry", World Trade Organization, 17 Eylül 2001, https://www.wto.org/english/news_e/pres01_e/pr243_e.htm (21.11.2020).

42 Alexander Cooley ve Daniel H. Nexon, "How Hegemony Ends", Foreign Affairs, 30 Ocak 2021, https://www.foreignaffairs.com/articles/united-states/2020-06-09/how-hegemony-ends (11.8.2020).

${ }^{43}$ Mustafa Kutlay, Global Power Shifts and Turkey- EU Relations in the Age of Hybridity (Paris: Institut du Bosphore, 2019), 3-5.

${ }^{44}$ Simon Shuster, "Why Angela Merkel Isn't Ready to Be the 'Leader of the Free World", Time, 12 Aralı 2016, https://time.com/4598467/angela-merkel-donald-trump-liberal-democracy/ (12.7.2020).
} 
bırakmayacaktır. ${ }^{45}$ Trump'ın Batı askeri ittifakının 70. yılı zirvesinde NATO'nun önemli bir amaca hizmet ettiğini belirtmesi, ABD’nin özgür dünya liderliğine dönüş sinyali olarak görülebilir. ${ }^{46}$ 2016'da NATO'yu köhnemiş olarak nitelendiren ve AB'nin savunma harcamalarına ayırdığı miktarı eleştirerek, bir yerde $\mathrm{AB}$ savunma entegrasyonunun güçlendirilmesi için itici güç olan Trump'ın seçilmesiyle, AB savunma stratejilerini yeniden ele almak durumunda kalmıştır. Bu doğrultuda Merkel, 2017'deki G7 zirvesinde, Avrupa'nın artık kendi güvenliğini ve kaderini teminat altına alması gerektiğini vurgulamıştır. ${ }^{47}$ Yeni Biden Yönetimi de Avrupa'yla yaşanan farklılaşmaları gidereceğini, ABD’nin, Trump öncesi uluslararası geleneklerine ve konumuna "geri döndüğünü” (America is Back) ilan etmiştir.

90'ların sonu ve 2000'lerin başında yumuşak güce sahip olma açısından zirvede olan ABD, bilgi teknolojisindeki üstünlüğü internet ve bilişim teknolojisindeki liderliğiyle ekonomik anlamda oldukça güçlenmiştir. Amerikan kültürü, dünyanın her yerinde piyasaya hâkim durumdaydı. Ancak sonraki dönemde, ABD’nin yumuşak gücünün azalmasıyla asıl yüzü ortaya çıkmıştır. ${ }^{48}$ Irak Savaşı'ndaki kendi çıkarlarını her şeyin üstünde gören tutumu, dışardan göçlere sıcak bakmaması, Uluslararası Ceza Mahkemesi’nin kararlarını tanımaması, dış borçlarını ödemekte yaşadığı sıkıntılar, ABD’nin küresel imajını olumsuz etkilemiştir.

ABD'nin askeri emperyalizminin ve küresel stratejilerini, özellikle de Irak ve Afganistan savaşları sonrasında emperyal aşırılıklar olarak ifade etmek yerinde olacaktır. Irak Savaşı sırasında trilyonlarca dolar olarak tahmin edilen nihai maliyetler ve askeri personel üzerindeki psikolojik bozukluklar, Amerikan savaş emperyalizminin ve savaş stratejilerinin çelişkilerinin altını çizmiştir. Irak savaşı, ABD’nin dünyanın önde gelen askeri gücü” rolünü azaltmasa da “ABD askeri gücünün güvenilirliğini tehlikeye atmış olmanın” yanı sıra, ABD hegemonyasının o dönemde yaşadığı krizin altında yatan temel bileşenlerden biri olarak değerlendirilebilir. ${ }^{49}$

\footnotetext{
45 Konstantin Richter, “Angela Merkel's New Job: Global Savior”, POLITICO, 17 Kasim 2016, https://www.politico.eu/article/donald-trump-angela-merkel-the-last-leader-of-the-free-world/ (12.7.2020).

${ }^{46}$ BBC News, "Nato summit: Trump blasts Macron 'brain dead' comments as "nasty",, 03 Aral1k 2019, https://www.bbc.com/news/world-europe-50641403 (12.7.2020).

${ }^{47}$ Hélène Emorine, "The European Union's Defence Strategy Gets an Overhaul”, Open Canada, 15 Şubat 2018, https://opencanada.org/european-unions-defence-strategy-gets-overhaul/ (31.10.2020).

${ }^{48}$ Joshua Kurlantzick, Charm Offensive: How China's Soft Power Is Transforming the World (New Haven: Yale University Press, 2007), 419-24.

49 Giovanni Arrighi, Globalization in World-Systems Perspective. Critical Globalization Studies, çev. R.P.Appelbaum ve W.I.Robinson Der. (New York: Routledge, 2005), 80.
} 


\subsection{Amerika Birleșik Devletleri’nin Gücünün Zayıfladığı Tezi}

20. yüzyıl süresince, Amerikan hegemonyasının birkaç kez düşüşe geçtiği iddia edilmiştir. İkinci Dünya Savaşı'ndan avantajlı ayrılsa da 1962'deki Küba Füze Krizi, 1975'te sona eren Vietnam Savaşı, 1980’lerde Japonya'nın ekonomisindeki hızlı büyüme ve son olarak 21. yüzyılın ilk örneği olarak 2008 Ekonomik Krizi sonrasında ABD ekonomisinin yavaş toparlanması ve Çin'in askeri gücünü hızla arttırması, ABD hegemonyasının düşüşte olduğu iddialarını gündeme getirse de bu durumun abartılı olduğu konusunda karşıt görüşler de mevcuttur..$^{50}$

Soğuk Savaş döneminden itibaren ABD’nin karşılaştığı jeopolitik rekabet, ayrıca onun hem uluslararası politik sistemi kutuplaştırmasının olumsuz etkileri, hem de kendi iç politikaları -2008'deki Büyük Regresyon'a neden olacak şekilde ekonomisini yanlış yönetmesi ve Ortadoğu ile Afganistan'da karıştığı bitmek bilmeyen savaşların ${ }^{51}$ sonuçları- Çin'in mevcut gücünü daha da arttırmasına yol açmıştır. ${ }^{52} \mathrm{Bu}$ küresel değişime bir örnek de 2008 yılının Kasım ayında gerçekleşen Küresel Ekonomik Zirve'de G8 ülkelerine Çin, Endonezya, Hindistan, Güney Afrika Cumhuriyeti gibi gelişmekte olan ülkelerin de eklenmesi ile G20'ye dönüşümün gerçekleşmesi olmuştur. G8 ülkelerinde sadece Japonya bir Asya ülkesi olarak bulunmaktayken, G20’de Asya ülkelerinin sayısı altıya (Avustralya, Çin, Hindistan, Endonezya, Japonya ve Güney Kore) yükselmiştir. Bu durum da Büyük Regresyon sonrasında, eskiden ABD ve Avrupa'da olan küresel ekonomik yönetim ve otoritesinin ağırlık merkezinin Asya'ya kaydığını göstermiştir. ${ }^{53} 2020$ yılında halka açık şirketlerin konsolide edilmiş verilere göre oluşturulan şirket büyüklüğü sıralamasında dünyada ilk 100'de ABD'li 37 şirket yer alırken, 18 Çin şirketi yer almıştır. ${ }^{54} \mathrm{Bu}$ kapsamda, 21. yüzyılda Amerikan hegemonyasının zayıflamasının nedenlerinden biri olarak gösterilen "güç kayması" kavramına değinmek gerekmektedir. Obama yönetiminin Asya Ulusal Güvenlik Konseyi direktörü Jeffrey Bader,

\footnotetext{
50 Joseph S. Nye, "Should China Be 'Contained'?", 2011, 195, http://belfercenter.hks.harvard.edu/ publication/21192/should_china_be_contained.html/ (28.5.2019).

${ }^{51}$ Biden Yönetimi, 20 yıldan sonra, Nisan 2021'de, “ABD'nin en uzun savaşına” bir son vererek, Afganistan'dan çekilme kararını açıklamıştır; Taliban da savaşı kendilerinin kazandığını ilan etmiştir (BBC Türkçe 2021 16, Nisan).

${ }^{52}$ Christopher Layne, "The US-Chinese power shift and the end of the Pax Americana", International Affairs 94, sy 1 (01 Ocak 2018): 90.

${ }^{53}$ Martin Wolf, "Three years and new fault lines threaten", Financial Times, 13 Temmuz 2010, blm. Opinion, https://www.ft.com/content/39c67712-8eb1-11df-8a67-00144feab49a (18.4.2019).

${ }^{54}$ Forbes, Global 2020: The World's Largest Public Companies", 2020, https://www.forbes.com/lists/global2000/ (25.1.2021).
} 
Çin'in son dönemdeki yükselişiyle sadece ABD'nin değil, bölgedeki tüm ülkelerin dikkatini çektiğini, bu ülkelerin her ne kadar Çin'le düşmanca ilişkiler kurmak istemeseler de Çin'in hâkimiyetine girmek yerine ona karşı dengelemeyi ABD ile işbirliği içerisinde sağlamak istediklerini belirtmiştir. ${ }^{55}$ ABD'nin İkinci Dünya Savaşı'ndan sonra kurduğu Pax Americana son dönemde erimektedir, ancak Trump bu durumun tek sebebi değildir, bu durumun hem iç hem de dış etkenleri bulunmaktadır. İç etken olarak, ABD’deki gelir dağılımının dengesizliğgi, büyümeyen reel gelirler, üretimde dışardan gelen hammadde bağımlılığı ve düşük verimlilik artışı; dış etken olarak ise, Pax Americana'nın Batı'nın egemenliğinde geçen dört yüzyılın ardından merkezinin Asya’ya kaymasıyla çökme tehlikesi söylenebilir. ${ }^{56}$

ABD hegemonyasının yapıtaşı olarak kabul edilen ve liberal hegemonik düzenin temel unsurları olan ticaret açıklığı, uluslararası alanda güvenlik sağlama garantisi ve liberal demokrasinin yayılması unsurlarının üçünde de zayıflama söz konusudur. Uluslararası ticaretin küresel üretimdeki payı olarak tanımlanan ve bir ülkenin küresel ticaret sistemine ne ölçüde dâhil olduğunun bir ölçüsü olan ticaret açıklığının Grafik 1'de görüldüğü gibi, 2009'da ekonomik krizden sonra çakılması ve 2011-2016 döneminde düşüş eğiliminde olması, ABD’nin gücünün zayıfladığına dair göstergelerden biri olarak kabul edilip, düşüşün süreceği şeklinde yorumlansa $\mathrm{da}^{57}$ (Huygens, 2017: 88), Trump döneminde yeniden artışa geçerek 2008'deki seviyesini yakalamıştır. Ancak dünyada ekonomik milliyetçiliğin artması, Brexit, ABD’nin Trans-Pasifik ve NAFTA konusundaki tutumları, ticaret açıklığının önümüzdeki dönemde de azalmasına neden olacaktır.

\footnotetext{
${ }^{55}$ Matt Spetalnick, “China High on Agenda for Obama's Asia Tour - Aide”, Reuters, 03 Kasım 2010, blm. Internal Reuters India Online Rpt Special Events 1, https://www.reuters.com/article/idINIndia-52631620101103 (17.4.2019).

${ }^{56}$ Layne, "The US-Chinese power shift and the end of the Pax Americana", 89-90.

57 Addison Daniel Huygens, American Decline and Changing Global Hegemony" (Iowa: Master Thesis of Political Science, Iowa State University, 2017), 88.
} 


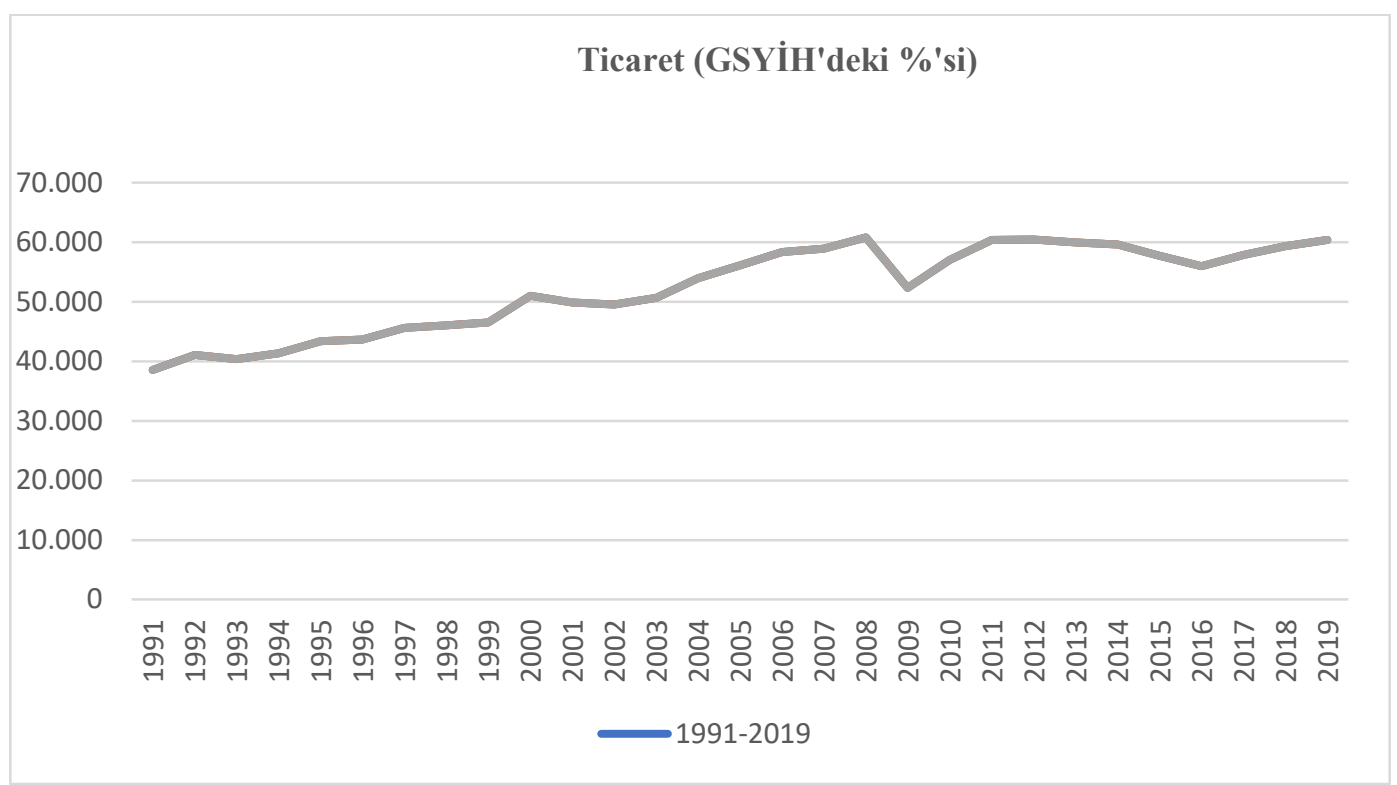

Grafik 1. Ticarete Açıklık Endeksi. ${ }^{58}$

\subsection{Amerika Birleşik Devletleri’nin Her Şeye Rağmen Hala Hegemon Olduğu İddiası}

Bir ülkenin gücündeki göreli değişimleri ölçmek zor olsa da onun diğer ülkelere göre gücünün ölçüsü ve onlar üzerindeki etkisi, askeri gücünün büyüklügü ve uluslararası sisteme uyguladığı siyasi etki derecesi gibi bazı temel göstergeler bu durumun anlaşılmasını kolaylaştırmaktadır. Hegemon bir devletin gücündeki büyük düşüş veya çöküş, savaş gibi nedenlere bağlı olabilirse de tarihte genellikle uzun vadede gerçekleşmiş bir süreçtir. ${ }^{59} \mathrm{ABD}$ özelinde bu duruma bakıldığında Irak’taki başarısızlığı ve mevcut Amerikan karşıtlığı gibi pek çok gerekçeye rağmen, ABD’nin güç üstünlüğünü gayet sağlam şekilde devam ettirdiği, Amerikan ordusunun dünyanın hala açık ara en güçlü ordusu olduğu görülmektedir.

Soğuk Savaş sonrasında, ABD, tarihte hiçbir ülkenin bu kadar kısa zaman aralığında girmediği kadar çok savaşa girmiş; 1989'da Panama'da, 1992-1993'te Somali'de, 1994'te Haiti'de, 1995-1996'da Bosna'da, 1999'da Kosova'da, 2001'de Afganistan'da ve Irak'ta üç kez (1991, 1998, 2003) olmak üzere, tam dokuz kez askeri müdahalede bulunmuştur. Bu müdahalelere rağmen, ABD’nin küresel ittifak ağı zarar görmemiştir. Bradley Thayer'ın gözlemlerine göre, dünyanın 190 ülkesinden, Amerikan karşıtı olan sadece beş ülke

58 The World Bank, "Trade (\% of GDP)", 2019, http://data.worldbank.org/indicator/ NE.TRD.GNFS.ZS?end=2020\&start=1991/ (12.9.2020).

${ }^{59}$ Adam Quinn, “The Art Of Declining Politely: Obama's Prudent Presidency and The Waning of American Power"', International Affairs 87, no. 4 (2011): 808. 
bulunmaktadır. Bunlar, Çin, Küba, İran, Kuzey Kore ve Venezuela'dır. Zaten, Soğuk Savaş sonrasında ABD'ye karşı sert bir dengeleme politikası uygulanmamış; bu tür dengeleme politikaları, daha çok Çin ve Rusya'ya yönelik olmuştur. ${ }^{60}$

Amerikan ekonomik göstergelerinin negatif olması da söz konusu değildir. Amerikan ekonomisi dünyanın en büyük (dünya GSYİH'sının yaklaşık yüzde 24'ü) ekonomisi olmakla birlikte dolar da neo-liberal sistemdeki küresel baskınlığını koruyarak, dünya rezerv para birimi olmaya devam etmektedir. Dünyada hükümetlerin sahip oldukları yabancı rezervlerin 2019 yılı itibarıyla yaklaşık yüzde 61'i dolarken, yüzde 20'si avro ve sadece yüzde 2' si yuandır. ${ }^{61}$ ABD, kendi para biriminin dünyada ortak para birimi olarak kullanılması sayesinde, dünyada dolarla yapılan bütün işlem provizyonlarının kendi üzerinden yapılması ve ülkeler arası para transferlerini manipüle etme gücüne de sahiptir. Çin, para biriminin dünya rezervlerindeki payını arttırmak istese de bu durumun gerçekleşebilmesi, güvenilir rezerv para birimi, para biriminin konvertibilite kolaylığg, güvenilir hükümet ve hukukun üstünlüğüne bağlıdır. Bununla birlikte, Çin'in dolar rezervlerini (3.2 trilyon) elden çıkarması veya doların değerini düşürmesi, Amerikan ekonomisine olduğu kadar kendi ihracatına ve ekonomisine de zarar verebilecektir . ${ }^{62}$ Uluslararası ticaret ve e-ticaret gibi pek çok alanda, doların konvertibilitesi, Alibaba gibi Çin firmalarına çok büyük kolaylıklar sağlamaktadır. İki ülke arasında çok büyük ayrışmalar olmadığı sürece de karşılıklı bağımlılık devam edecektir. Doların bu anlamdaki üstünlüğü, ABD’nin finansal yaptırımlarda aşırıya kaçması gibi nedenlerle diğer devletler için de sonsuza dek süremeyecek olsa da, yuanın yakın gelecekte doların yerini alması olası görünmemektedir. Bununla birlikte, ABD’nin gelecekte liberal düzenini genişletmesi ve kurumsallaştırması halinde, Çin'in bu düzene katılım ve uyum sağlamaktan başka çaresi kalmayacaktır. ABD’nin amac1, gücünü göz önüne alarak, diğer devletlerle birlikte oluşturulan mevcut liberal kural ve kurumlara bağlı faaliyetlerin Çin tarafından da kullanıldığını görmek olmalıdir.

ABD dışındaki diğer tüm ülkeler, uluslararası gücün, ekonomi veya kültür gibi tek bir boyutuna bağlıdır, bu nedenle etkileri tek boyutludur. ABD'nin gücü de uluslararası alana etkisi

\footnotetext{
${ }^{60}$ Robert Singh, “The Exceptional Empire: Why the United States Will Not Decline - Again", International Politics 45, no. 5 (01 Eylül 2008): 576.

${ }^{61}$ International Money Fund, "World Currency Composition of Official Foreign Exchange Reserves", 2019, https://data.imf.org/?sk=E6A5F467-C14B-4AA8-9F6D-5A09EC4E62A4 (23.1.2021).

${ }^{62}$ Joseph S Nye, "Perspectives for a China Strategy", PRISM 8, no. 4 (2020): 125.
} 
de çok boyutludur. ABD, nüfus büyüklüğü, eğitim kalitesi, sahip olduğu doğal kaynaklar, finansal kalkınması, sosyal uyumu, siyasal istikrarı, askeri güç kapasitesi, ideolojik çekiciliği, kurduğu diplomatik ittifakları ve teknolojik üstünlüğü ile genel etkisini muhafaza etmektedir. ${ }^{63}$

\section{Güncel Gelişmeler Işı̆̆ında Amerikan Hegemonyasının Geleceği: Sert Güç ve Yumuşak}

\section{Güç Açısından Çin'in Alternatif Hegemonyası ile Karşılaştırılması}

Bu bölümde Çin'in mevcut hüküm süren ABD hegemonyasına alternatif olma durumu, hegemonyanın ana unsurları açısından ele alınacak ve Çin'in hegemon olacağına dair görüşler ile bu duruma zıt görüşler birlikte değerlendirilecektir.

ABD'nin Irak işgali sonrasında yaşadığı prestij kaybı, Çin'in artık bir hegemon olarak ABD'nin yerini almaya başladığı yönündeki iddiaları güçlendirmiştir. Bu durum, ABD’nin siyasi etkinliğini kaybetmese de askeri başarısızlığa uğradığı Vietnam Savaşı sonrasında geliştirilen ABD’nin gerilemesi tezi ile benzerlik göstermektedir. ${ }^{64}$ Bununla birlikte Trump dönemi, hâlihazırda tarih boyunca karmaşık durumdaki ABD-Çin ilişkilerinin öngörülemezliğini iyice arttırmıştır. Çin'in 21. yüzyılda, 20. yüzyıldaki Kayser Almanyası kadar tehlikeli olduğunu iddia eden akademisyenler bulunmaktadır. Çin'in yükselen gücü, Birinci Dünya Savaşı gibi büyük bir tarihi felakete yol açabilir. Antik Çağ'daki Peloponez Savaşı'nın sebebi de yalnızca Atina'nın gücünden kaynaklı değil, Sparta'nın Atina üzerinde oluşturmuş olduğu korkudand1. ${ }^{65} \mathrm{Bu}$ noktada en büyük soru işareti, Çin'in rolüyle ilgili olacaktır.

Güç açısından daha zayıf durumda olanların bile karşı taraf için büyük zararlara neden olduğu asimetrik savaş çağında, askeri güç, daha az etkili hale gelmiştir. Ancak ABD, hala askeri olarak muazzam gücünü korumakta olup, dünyanın herhangi bir yerine müdahale etme kapasitesine sahiptir. Aynı zamanda ABD, Asya ve Avrupa'nın güvenliğinin ana sağlayıcısıdır ve günümüzde başka hiçbir ülke, uluslararası sistemin tamamına güvenlik garantisi verememektedir. SSCB'nin dağılmasından sonra azalan ABD askeri harcamaları, 11 Eylül Saldırısı ve sonrasında dünyadaki ikinci kademe güçlerin askeri harcamalara ağırlık vermek yerine ABD güvenlik şemsiyesini kabullenmeleri gibi nedenlerden dolayı, Grafik 2'de

\footnotetext{
${ }^{63}$ Hawre Hasan Hama, "Is the United States Still a Global Hegemonic Power?", International Journal of Social Sciences \& Educational Studies 3, no. 2 (01 Aralık 2016): 112.

${ }^{64}$ John Lee, “America Rising: Indispensible Again in Asia”, World Affairs 179, no. 1 (01 Haziran 2016): 22.

65 Thucydides, Peloponnessos Savaşları, çev. Furkan Akderin (İstanbul: Belge, 2020), 115.
} 
belirtildiği gibi, dünya genelinin yüzde $38^{\prime}$ 'ini oluşturmaktadır, bu oran Çin'in yaklaşık üç katidir.

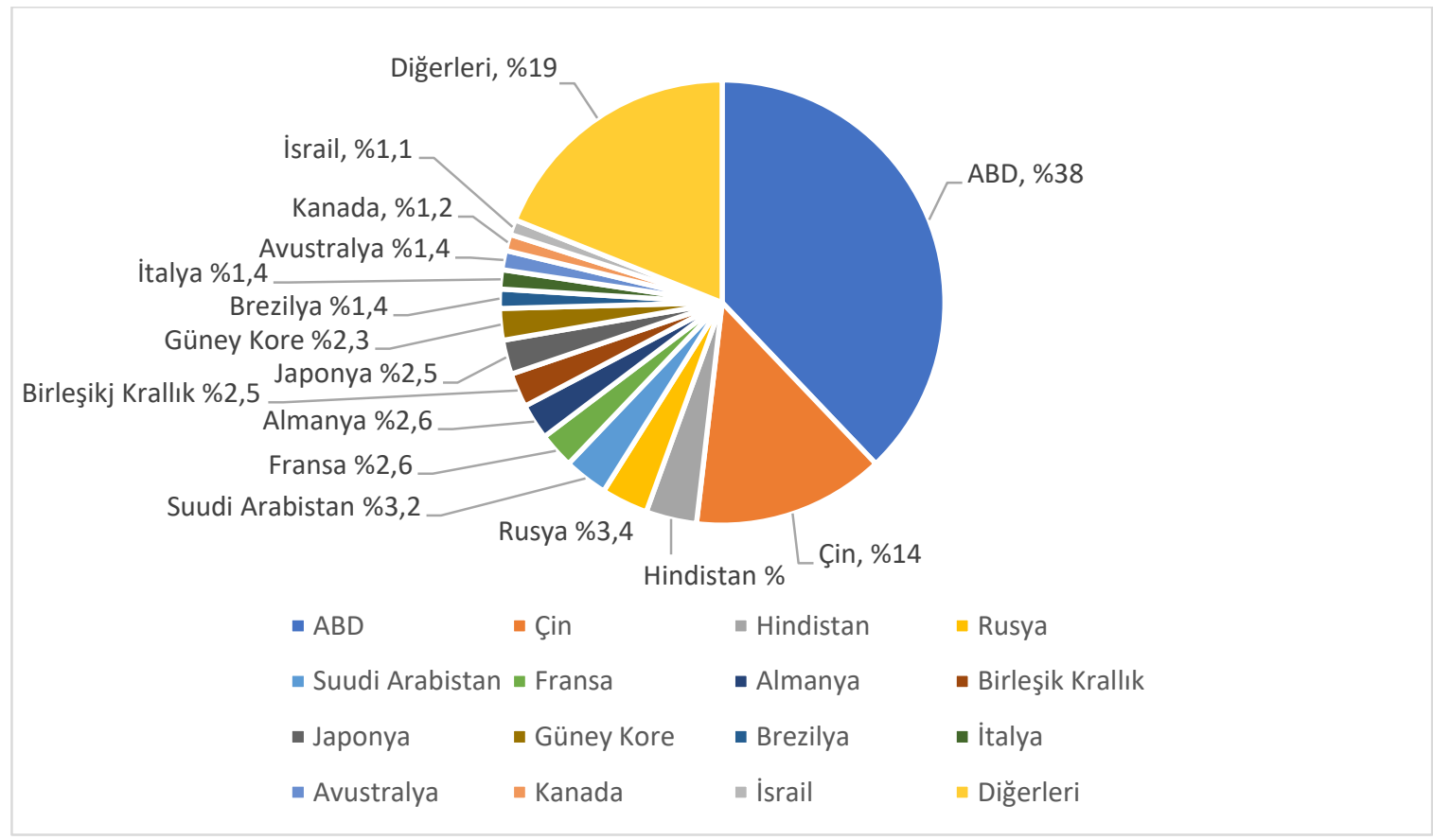

Grafik 2. 2019'da en çok harcama yapan 15 ülkenin dünya askeri harcamalarındaki payları. ${ }^{66}$

ABD’nin dünyada halen pek çok müttefiki bulunmaktadır. Diğer ülkelerle dikkatli bir şekilde asimetrik de olsa karşılıklı bağımlılıklar ve tarihsel ilişkiler çerçevesinde kurulan resmi bağlantılar devam etmektedir. Bir dizi ticaret anlaşması ve ittifakların yanı sıra ABD’nin 70 kadar ülkede konumlu 800 civarında askeri üssü bulunmaktadır. ${ }^{67}$ ABD’nin güvenlik garantörlüğü konusunda Avrupa, Latin Amerika, Afrika ve Asya'daki kilit ülkelerde alternatifinin olmadığı görülmektedir. Amerikan hegemonyası, yalnızca kendi iradesiyle var olmaktan öte, diğer ülkelerin çıkarları gereği bu durumu kabullenmeleriyle de varlığını devam ettirmektedir.

ABD'de her politikacı, yetkili ve stratejist, ABD'nin dünya üzerinde mümkün olabilecek en fazla güce sahip olmasını arzu etmektedir. Bu kapsamda, güç maksimizasyonu ile ilgili Tablo 1'de belirtilen dört farklı düşünce tarzı tipolojisi önerilmiştir.

66 "SIPRI Military Expenditure Database", Stockholm International Peace Research Institute, 2020, https://www.sipri.org/databases/milex (11.8.2020).

${ }^{67}$ Cengiz Dinç ve Bekir Karataş, “Amerikan Karşıtllğında Güncel Küresel Eğilimler ve Trump Etkisi”, OPUS Uluslararası Toplum Araştırmaları Dergisi 9, no. 16 (25 Aralık 2018): 1992-2032. 
Çin'in çevresindeki ülkelerden toprak talepleri nedeniyle yumuşak güç unsurlarını etkili kullanması mümkün olmamaktadır. Çin'in yardım programları, olimpiyat ve fuar etkinlikleri, Konfüçyüs Enstitüleri, Asya Altyapı Yatırım Bankası vb. dünyada ilgi görse de çoğunlukla devlet girişimleri olduğu için sınırlı etkiye sahiptir. ABD ise daha çok sivil toplum üzerinden kültür alanında yumuşak gücü tesis etmektedir ki bunun en etkili yöntem olduğu savunulmaktadır. ${ }^{68}$ Çin, politik değerlerini dünyaya ihraç etmekte de zorluklar yaşamaktadır. Küresel güç ilişkilerinde, askeri güçle birlikte ekonomik güç ve ulusaşırı ilişkilerin de var olduğu "karmaşık üç boyutlu satranç oyunu" söz konusudur. ${ }^{69}$

\section{1. Çin'in Amerikan Hegemonyasının Alternatifi Olması Üzerine Görüşler}

Goldman Sachs, 2027 y1lına kadar Çin ekonomisinin Amerikan ekonomisinden daha büyük olacağını öngörmüştür. Her ne kadar 2020'lerin ortalarına kadar, Çin'in ABD’yi piyasa döviz kuruyla ölçülen GSYİH bazında geçeceği tahminine rağmen, son olarak yayınlanan 2019 nominal GSYİH verilerine göre, ABD, Çin'den üstün durumda olsa $\mathrm{da}^{70}$ son dönemde askeri alanda “iki savaş” stratejisindeki askeri kapasitesini kaybeden ABD’nin Tablo 2'de belirtildiği üzere, satın alma gücü paritesinde de Çin'in gerisinde kaldığ belirtilmiştir. ${ }^{71}$ Bununla birlikte, kişi başına düşen GSYİH'nin, toplam GSYİH'ye göre daha geçerli bir ulusal güç ölçütü olduğu, Çin'in ileri teknolojide ABD’nin çok gerisinde ve inovasyon konusunda hala yetersiz olduğu da bilinmektedir. ${ }^{72}$

\footnotetext{
${ }^{68}$ Joseph Samuel Nye, Is American Century Over? (Cambridge: Polity Press, 2015), 59-60.

${ }^{69}$ A.g.e., 95-97.

${ }^{70}$ I.H.S. Markit, China to Become World's Largest Economy in 2024 Reports IHS Economics", 2014, https://news.ihsmarkit.com/press-release/economics-country-risk/china-become-worlds-largest-economy-2024reports-ihs-economics/; “Comparing United States and China by Economy”, Statistics Times, 19 Haziran 2021, https://statisticstimes.com/economy/united-states-vs-china-economy.php/ (17.4.2019).

${ }^{71}$ Patrick Cullen, “The Rebalance to Asia Under Trump”, The RUSI Journal 162, no. 2 (04 Mart 2017): 11.

${ }^{72}$ Abrami, Regina M., William C. Kirby, ve F. Warren McFarlan. "Why China can't innovate". Harvard business review 92, no. 3 (2014): 107-11.
} 
Tablo 1. Güç Maksimizasyonu Tipolojisi: Dört Alternatif Öncelik ${ }^{73}$

\begin{tabular}{|c|c|c|c|c|}
\hline & $\begin{array}{l}\text { Güç Farkını } \\
\text { Maksimuma } \\
\text { Ulaştıran }\end{array}$ & $\begin{array}{l}\text { Tahakkümü } \\
\text { Maksimuma } \\
\text { Ulaştıran }\end{array}$ & $\begin{array}{c}\text { Etkiyi Maksimuma } \\
\text { Ulaştıran }\end{array}$ & $\begin{array}{l}\text { Liberal Düzenin } \\
\text { Ömrünü } \\
\text { Maksimuma } \\
\text { Ulaştıran } \\
\end{array}$ \\
\hline $\begin{array}{l}\text { Stratejik } \\
\text { Amaç }\end{array}$ & $\begin{array}{c}\text { Öncelik; Halk } \\
\text { Tabakasının } \\
\text { Yönetimi }\end{array}$ & İtaat Gösterme & Başkalarının Üzerinde Etki & $\begin{array}{l}\text { Ayrıcalıklı } \\
\text { Normların } \\
\text { Hegemonyası }\end{array}$ \\
\hline $\begin{array}{l}\text { Öncelikli } \\
\text { Analitik } \\
\text { Odak }\end{array}$ & $\begin{array}{l}\text { Göreceli Ulusal } \\
\text { Güçler }\end{array}$ & $\begin{array}{l}\text { Güçlerin Zor } \\
\text { Kullanma } \\
\text { Uygulaması }\end{array}$ & $\begin{array}{c}\text { Karşılıklı Anlaşma Sonucu } \\
\text { Ortaya Çıkacak Teknik } \\
\text { Sonuçları İçeren } \\
\text { Mekanizmalar }\end{array}$ & $\begin{array}{l}\text { Uluslararas1 } \\
\text { Toplumsal } \\
\text { Düzen }\end{array}$ \\
\hline $\begin{array}{l}\text { İstenilen } \\
\text { Davranış } \\
\text { Şekli }\end{array}$ & Kabullenme & $\begin{array}{l}\text { Otoriteyle } \\
\text { Uyum }\end{array}$ & Biçimlendirilmiş Tercihler & $\begin{array}{c}\text { Paylaştırılan } \\
\text { Tercihler }\end{array}$ \\
\hline $\begin{array}{l}\text { Öncelikli } \\
\text { Araçlar }\end{array}$ & $\begin{array}{l}\text { Askeri Harcamalar; } \\
\text { Ekonomik Büyüme }\end{array}$ & $\begin{array}{l}\text { Askeri Tehdit } \\
\text { veya } \\
\text { Ekonomik } \\
\text { Yaptırım }\end{array}$ & $\begin{array}{c}\text { Kurum Geliştirme ve } \\
\text { Diplomasi }\end{array}$ & $\begin{array}{c}\text { Örnek ve Sosyal } \\
\text { Uyum }\end{array}$ \\
\hline
\end{tabular}

Tablo 2. ABD, Çin ve AB'nin Satın Alma Gücü Pariteleri (PPP) Verileri ${ }^{74}$.

\begin{tabular}{|l|l|c|c|}
\hline & $\begin{array}{c}\text { IMF 2020 } \\
\text { Tahmini } \\
\text { (GDP millions of } \\
\text { current int \$) }\end{array}$ & $\begin{array}{c}\text { Dünya Bankasi } \\
\text { 2019 Verileri } \\
\text { (GDP millions of } \\
\text { current int \$) }\end{array}$ & $\begin{array}{c}\text { CIA The World Factbook } \\
\text { 2017 Verileri } \\
\text { (GDP billions of current int \$) }\end{array}$ \\
\hline ABD & 20.807 .269 & 21.427 .700 & 19.360 \\
\hline Çin & 24.162 .435 & 23.460 .170 & 23.120 \\
\hline AB & 19.397 .267 & 20.794 .743 & 20.850 \\
\hline
\end{tabular}

Çin, bilimde ve eğitimde yıllardır ABD’nin gerisindedir. Dünyada 2021 yılı için belirlenen en iyi üniversiteler sıralamasında ABD’nin 151 üniversitesi yer almaktayken, Çin'in sadece 41 üniversitesi vardır. ${ }^{75}$ Çin hükümetinin ciddi miktarda bütçe ayırmasıyla Çin üniversiteleri, uluslararası alanda önemli yerlere gelmelerine rağmen; üniversitelerin özerk yapıya sahip olmamaları, Çinli akademisyenlerin akademik araştırmalardan çok bürokratik rütbe peşinde koşmaları, Çin'deki yükseköğretime yönelik doğrudan hükümet sansürü ve hükümet fonlamalarının üniversitelere adil ve dengeli dağıtılmaması gibi nedenler, bu

\footnotetext{
${ }^{73}$ Adam ve Kitchen Quinn ve Nicholas, "Understanding American Power: Conceptual Clarity, Strategic Priorities, and the Decline Debate", Global Policy 10, no. 1 (2019): 12.

${ }^{74}$ The World Bank, "GDP, PPP (Current International \$) - China, United States, European Union”, 2019, https://data.worldbank.org/indicator/NY.GDP.MKTP.PP.CD (25.5.2021).

75 "QS World University Rankings 2021".
} 
üniversitelerin uluslararası alandaki rekabette geride kalmalarına neden olmaktadır. ${ }^{76}$ Ayrıca Tablo 3'te ifade edildiği gibi, Çin ve ABD arasında yükseköğretim eğitimine sahip insan sayısında ve beşeri sermayede önemli farklar bulunmaktadır.

Tablo 3. Beşeri Sermaye ${ }^{77}$

\begin{tabular}{|c|c|c|c|}
\hline & Y1llı Doktora Sayıs1 (2010) & $\begin{array}{c}\text { Yükseköğretim Eğitime Sahip } \\
\text { İnsan Sayıs1 (Milyon) (2012) }\end{array}$ & $\begin{array}{c}\text { Beşeri Sermaye } \\
\text { Seviyesi (Milyar ABD } \\
\text { doları) (2010) }\end{array}$ \\
\hline ABD & 32.649 & 70,2 & 99.641 \\
\hline Çin & 31.410 & 31,1 & 13.447 \\
\hline
\end{tabular}

Çin'in son dönemde yakaladığı ekonomik yükseliş ivmesiyle birlikte, pek çok kişi, Çin'in ABD'nin mutlak egemenliğine son vererek yeni ve daha eşitlikçi bir düzeni teşvik etmek amacıyla ortaya çıkan BRICS'in en güçlü ülkesi olduğu görüşünü savunmaktadır. Ancak ABD'nin küresel gücünün düşmesi ve Çin'in Pax Americana'nın dışında yeni süper güç olarak yükselişini vurgulamak, Almanya ve Japonya'nın 1970’lerdeki yükselişindeki gibi olduğundan daha fazla abartılmış olabilir. ABD’nin politik gücünün gerilemesi durumu, yavaşlama veya erteleme olarak düşünülebilir. ABD’nin küresel GSYİH' deki payı yüzde 20'nin üzerinde konumunu istikrarlı bir şekilde korumaktadır ve $\mathrm{ABD}$, dünyanın en büyük ekonomisi olmaya devam etmektedir. Çin'in bugün ABD'ye kafa tutan ekonomisinin temel direği olan ihracat değerinin ${ }^{78}$ büyük bir kısmı, bol ve ucuz işgücünden faydalanmak amacıyla Çin'de faaliyet gösteren Avrupalı ve Amerikan şirketleri sayesinde gerçekleşmektedir (Strauss, 2018).

Ekonomik ve iç politik nedenlerinin yanı sıra Bir Kuşak, Bir Yol Projesi'ni gerçekleştirmek için Çin'in uluslararası gerekçeleri de bulunmaktadır. Aşağılanma Çağı'nın (1839-1949) başlangıcından beri Çin ilk kez uluslararası politikada avantajlı ve güçlü konumdadır. Çin, günümüzde Deng Şiaoping'in 1992'ye kadar süren düşük profilli politikasının tam tersi bir politika benimseyerek kendi uluslararası planının lideri ve finansörü

\footnotetext{
76 Martin Longman ve Josh Freedman, "Higher Red", Washington Monthly, 26 Ekim 2016, https://washingtonmonthly.com/magazine/novemberdecember-2016/higher-red/ (15.11.2020).

${ }^{77}$ Stephen G. Brooks ve William Curti Wohlforth, America abroad: the United States' global role in the 21st century (New York, NY: Oxford University Press, 2016), 16.

78 The World Bank, "Exports of goods and services (BoP, current US\$)", 2019 (12.6.2020), https://data.worldbank.org/indicator/BX.GSR.GNFS.CD/ (12.6.2020).
} 
olmuştur. ${ }^{79}$ Çin, Xi’nin iktidarı sonrasında kural koyucu bir ülke olarak, kendisini serbest ticaretin ve çok taraflılığın savunucusu bir ülke olarak liberal, kapitalist demokrasiye alternatif olarak görmektedir. ${ }^{80}$ Bununla birlikte, Asya Pasifik'te artık çok az sayıda ülke Pekin'in yükselişine bel bağlamaktadır. Çin'in komşularıyla yaşadığı gerginliklerin artması, bölgedeki ticaretin yavaşlamasına neden olmaktadır. Buna karşılık, pek çok ihracata bağımlı ekonomi, gitgide merkantilist (korumacı/iktisadi milliyetçi) ticaret politikalarını benimsemek durumunda kalmıştır ve ekonomik ilişkilerde sıfır toplamlı oyun anlayışını benimsemektedir. Bu durumlar yaşanırken Amerikan ekonomisi, yeniden hayata dönmüştür. Yeni enerji revizyonu, Amerikan şirketlerinin maliyetlerini düşürmüş, böylece diğer ülkelerin şirketleriyle rekabet güçleri ve ticari denge iyileşmiştir. Öyle ki Asya şirketleri, artık on yıl öncesiyle kıyaslanırsa, Amerikan şirketlerinin inovasyonuna, sermayesine ve pazarlarına daha bağımlı hale gelmiştir. ${ }^{81}$

ABD’nin küresel ekonomideki payının gelecek yıllarda artacağı kesindir, çünkü Çin ekonomisinin büyüklüğü, 2008-2015 yılları arasında 3 trilyon dolardan 34 trilyon dolara çıkmıştır ve bu ekonomik büyüme hızını düşürmek zorunda kalacağına kesin gözüyle bakılmaktadır. Bu durum, Japonya'nın ekonomik patlama yaşadığı 1980'li yıllardan sonra durgunluğa girdiği ve devamını getiremediği sürecin bir benzeri olacaktır. Çin, her ne kadar bütün gelecek senaryolarında büyük ve önemli bir ekonomik aktör olarak görülüyor olsa da ekonomik açıdan çevresindeki ülkelerin geleceğini belirlemekten, onlar üzerinde tam hâkimiyet kurmaktan şimdilik uzaktır. ${ }^{82}$

2015 yılında Çin hükümeti tarafından önerilen ve paralel bir küresel finans düzeni olacağı iddia edilen Asya Altyapı Yatırım Bankası (AIIB), Çin’in yükselişine kanıt olarak gösterilebilir. Üstelik Avustralya ve Birleşik Krallık gibi ABD’nin önemli müttefiklerinin bu kuruma üye olmaları, küresel gücün doğuya doğru kaymasıyla ilgili en önemli göstergelerden birisidir. ${ }^{83}$ Çin, AIIB'nin yanı sıra İpek Yolu Fonu, Şangay İşbirliği Örgütü, ASEAN Plus One gibi çok taraflı oluşumlarla küresel düzeni reddetmek yerine, onu tamamlayıp, yeniden

\footnotetext{
${ }^{79}$ Michael Pillsbury, The Hundred Year Marathon; China's Secret Strategy to Replace America as the Global Superpower (New York: Henry Holt and Company, 2015), 183.

${ }^{80}$ Rebecca Liao, "China's New Helmsman: Where Xi Jinping Will Take the Middle Kingdom Next"”, Foreign Affairs, 2017, 3.

${ }^{81}$ Lee, "America Rising", 23.

${ }^{82}$ A.g.e., 26.

${ }^{83}$ Jan Fichtner, "Perpetual Decline or Persistent Dominance? Uncovering Anglo-America's True Structural Power in Global Finance", Review of International Studies 43, no. 1 (Ocak 2017): 4.
} 
şekillendirerek, kendi Bretton Woods'unu oluşturma amacı taşımaktadır. ${ }^{84}$ Çin, ana amacının jeopolitik çıkarlar değil ortak kalkınma ve karşılıklı refah sağlama olduğunu vurgulasa da diplomatik güveni sağlama konusunda hala eksiklikleri mevcuttur.

Son yıllarda Asya, Amerikan dış politikasında öncelikli konuma yükselmiştir. ABD’nin Çin hakkındaki kaygıları, yalnızca Çin'in askeri gücünü arttırması ve kendi müttefikleriyle anlaşmalar yapmasıyla değil, aynı zamanda her anlamda yükselmekte olan Çin'i kontrol altına alma çabasıyla da ilgilidir. ABD, jeopolitik açıdan Çin'i bölgesel bir güç olarak sınırlı kalmaya, jeostratejik açıdan da kendi hegemonyasına tehdit oluşturmasını önlemeye çalışmaktadır. $\mathrm{Bu}$ bağlamda, Mearsheimer'ın belirttiği gibi ABD, Asya'da Çin'in komşularının çoğunu kapsayan bir koalisyon kurarak Çin'i çevrelemeye ve Çin'in Asya'ya hükmetmesini önlemeye çalışacaktır. ${ }^{85}$ Çin için de ABD’nin mevcut hegemonyasına meydan okumak, yalnızca ekonomik anlamda meydan okumaktan çok daha zor olacaktır.

Çin'in demokratik olmayan siyasal sistemi, ABD'ye yönelik ideolojik bir tehdit olarak görülebilir. Eğer Asya, otoriter bir Çin tarafından yönetilirse, ABD’nin bölgedeki liberal reform beklentileri sekteye uğrayacaktır. Hatta Asya'da yerleşik demokrasiye sahip ülkeler bile bu durumdan etkilenerek, Çin'i karşılarına alacak politikalardan kaçınmak zorunda kalabileceklerdir. Ekonomik sıkıntılara sahip olmakla birlikte, askeri harcamalarındaki çift haneli artış, Japonya'ya karşı Senkaku Adaları'nda olduğu gibi tahrik edici hareketlerde bulunması ve Güney Çin Denizi'ndeki yapay adalarını silahlandırması gibi etkenler, Çin'in ABD ile arasındaki sorunları derinleştirmektedir. ABD’nin bölgedeki müttefiki olan ülkelerden Avustralya, Çin'in Güney Çin Denizi'ndeki faaliyetleri ve sert güç kullanma ihtimalinden endişe duymaktadır. Burma, Amerikan filosuyla daha yakın askeri ilişki kurmayı talep etmektedir. Singapur, Amerikan savaş gemilerine hizmet etmek amacıyla donanma tesisleri inşa etmiştir. Malezya, ABD ile istihbarat ağlarını sürekli geliştirmektedir. George W. Bush döneminde temellenen Hindistan'ın stratejik müttefikliği devam etmektedir. İstisnai olarak Tayland, Çin'in hâkimiyetine sürüklenmektedir; bölgede ABD karşıtı Kuzey Kore de

84 Tom Miller, “A Chinese Bretton Woods?”, Gavekal Research, (12 Haziran 2014), https://research.gavekal.com/user/login?destination=node/8800 (12.6.2020).

${ }^{85} \mathrm{John}$ Mearsheimer, Mearsheimer on Strangling China \& the Inevitability of War, röportaj yapan Peter Navarro, 03 Ekim 2016, https://www.huffpost.com/entry/mearsheimer-on-strangling_b_9417476 (28.5.2019). 
bulunmaktadır. Bölgedeki diğer ülkelerin hemen hemen tamamı, Asya'da ABD'nin bulunmadığı hiçbir askeri dengenin kalıcı olamayacağı konusunda hemfikirdir. ${ }^{86}$

Özellikle Trump'ın seçilmesinden sonra ABD hükümetine olan güven azalmışsa da bu durum Tablo 4'te görüldüğ̈̈ gibi çıkar odaklı hareket eden diğer hükümetlerin tutumlarına yansımamıştır. Bu durumun temel sebebi, Rusya ve Çin liderlerinin -tıpkı Trump gibi- güvenilir bulunmamaları nedeniyle, ona alternatif oluşturamamalarıdır. Tablo 5'te görüldüğü gibi dünyadaki en güçlü devletlerin Çin'e karşı yönelimlerinde negatif tutum daha ağırlıktadır.

Tablo 4. Bazı Küresel ve Bölgesel Güçlerin ABD’ye Bakış Açıları ${ }^{87}$

\begin{tabular}{|c|c|c|c|c|c|c|}
\hline & $\begin{array}{l}\text { Nüfus } \\
\text { (Milyon } \\
\text { kişi) }\end{array}$ & $\begin{array}{c}\text { GSYİH } \\
\text { Nominal } \\
\text { (Triyon \$) }\end{array}$ & $\begin{array}{c}\text { GSYIH } \\
\text { SGP } \\
\text { (Trilyon \$) }\end{array}$ & $\begin{array}{c}\text { Askeri } \\
\text { Harcamalar } \\
2017 \\
\text { (Milyar \$) } \\
\end{array}$ & $\begin{array}{c}\text { Askeri } \\
\text { Harcamalar/Devlet } \\
\text { Harcamaları } 2017\end{array}$ & $\begin{array}{l}\text { ABD'ye Karşı } \\
\text { Tanımlanan } \\
\text { Tutumu }\end{array}$ \\
\hline $\mathrm{ABD}$ & 327 & 19.36 & 19.36 & 609.8 & $\% 8.8$ & - \\
\hline Çin & 1391 & 11.94 & 23.12 & 228.2 & $\% 6.1$ & $\begin{array}{c}\text { Potansiyel } \\
\text { Hegemon/ } \\
\text { Yumuşak } \\
\text { Dengeleme }\end{array}$ \\
\hline $\begin{array}{c}\text { Avrupa } \\
\text { Birliği }\end{array}$ & 516 & 16.52 & 19.97 & 258.7 & $\% 3.3$ & $\begin{array}{c}\text { Destek/Yumuşak } \\
\text { Dengeleme/Kismi } \\
\text { Ekonomik } \\
\text { Sürtüşme } \\
\end{array}$ \\
\hline Rusya & 146 & 1.46 & 4 & 66.3 & $\% 12$ & $\begin{array}{c}\text { Rakip/Bölgesel } \\
\text { Aktif Dengeleme }\end{array}$ \\
\hline Hindistan & 1332 & 2.43 & 9.447 & 63.9 & $\% 9.1$ & $\begin{array}{c}\text { Orta Derecede } \\
\text { Destek/Bazı } \\
\text { Konularda } \\
\text { Sürtüşme } \\
\end{array}$ \\
\hline Japonya & 126 & 4.88 & 5.405 & 45.4 & $\% 2.6$ & Destek \\
\hline Almanya & 82 & 3.65 & 4.15 & 44.3 & $\% 2.7$ & $\begin{array}{c}\text { K1smi } \\
\text { Destek/Ekonomik } \\
\text { Sürtüşme } \\
\end{array}$ \\
\hline $\begin{array}{l}\text { Birleşik } \\
\text { Krallık }\end{array}$ & 65 & 2.56 & 2.88 & 47.2 & $\% 4.7$ & Yüksek Destek \\
\hline İtalya & 62 & 1.92 & 2.307 & 29.2 & $\% 3.1$ & $\begin{array}{c}\text { K1smi } \\
\text { Destek/Ekonomik } \\
\text { Sürtüşme } \\
\end{array}$ \\
\hline Fransa & 67 & 2.57 & 2.826 & 57.8 & $\% 4$ & Yüksek Destek \\
\hline Brezilya & 207 & 2.08 & 3.219 & 29.3 & $\% 3.7$ & Destek \\
\hline $\begin{array}{l}\text { Körfez } \\
\text { İşbirliği }\end{array}$ & 54 & 1.50 & 3.46 & 126.7 & $\% 21.3$ & Yüksek Destek \\
\hline
\end{tabular}

\footnotetext{
${ }^{86}$ Lee, "America Rising”, 29.

${ }^{87}$ Dinç ve Karataş, “Amerikan Karşıtlığında Güncel Küresel Eğilimler ve Trump Etkisi”, 17.
} 
Tablo 5. Seçilmiş Bazı Ülkelerin Çin'e Karşı Tavırları ${ }^{88}$

\begin{tabular}{|c|c|c|}
\hline & Olumlu (\%) & Olumsuz (\%) \\
\hline $\mathrm{ABD}$ & 26 & 60 \\
\hline Rusya & 71 & 18 \\
\hline İspanya & 39 & 53 \\
\hline İngiltere & 38 & 55 \\
\hline İtalya & 37 & 57 \\
\hline Hollanda & 36 & 58 \\
\hline Almanya & 34 & 56 \\
\hline Fransa & 33 & 62 \\
\hline İsveç & 25 & 70 \\
\hline Kanada & 27 & 67 \\
\hline Avustralya & 36 & 57 \\
\hline Endonezya & 36 & 36 \\
\hline Güney Kore & 34 & 63 \\
\hline Hindistan & 23 & 46 \\
\hline Japonya & 14 & 85 \\
\hline İsrail & 66 & 2 \\
\hline Türkiye & 37 & 44 \\
\hline Nijerya & 70 & 17 \\
\hline Güney Afrika Cumh. & 46 & 35 \\
\hline Brezilya & 51 & 27 \\
\hline Meksika & 50 & 22 \\
\hline Arjantin & 47 & 24 \\
\hline
\end{tabular}

Sonuç olarak Çin'in ekonomik ve askeri çıkarlarını yüceltmek amacıyla daha fazla fırsat kollayacağı ve ABD’nin bu durumu engellemek adına çaba göstereceği öngörülebilir. Bu noktada esas sorun, olası yeni güç dağılımındaki değişimlerin ABD’yi ve uluslararası güvenliği nasıl etkileyeceğidir.

\footnotetext{
${ }^{88}$ Laura Silver, Kat Devlin, ve Christine Huang, "China's Economic Growth Mostly Welcomed in Emerging Markets, but Neighbors Wary of Its Influence" (Pew Research Center, Aralık 2019), https://www.pewresearch.org/global/2019/12/05/attitudes-toward-china-2019/ (10.6.2020).
} 
Asya Pasifik'teki güvenlik kaygılarının geçerli sebepleri bulunmaktadır. Çin'in elde ettiği ekonomik refahta ABD’nin oynadığı olumlu rolün büyük payı bulunmaktadır. Çin'in kırk y1llık sürdürülebilir ekonomik büyümesinde ABD ile ilişkisinin rolü yadsınamaz. Çin, her ne kadar kendi iç dinamiklerine güveniyor olsa da, yabancı (ABD dahil) ekonomik ve politik güçlerin toptan reddedilmesi, Çin için büyük bir kayıp olabilir. ABD’nin gücünü koruyor olması, Çin'in ekonomik çıkarınadır. ${ }^{89}$

Mevcut hegemonyanın kurguladığı düzenin kolay kolay yıkılamayacağı açıktır. Kaldı ki, yeni bir hegemon ortaya çıksa bile uzun yıllar boyunca kurulu küresel çarkın dönmeye devam etmesine izin vermek zorunda kalacaktır. Bu sebeple de mevcut düzenin tamamen yıkıldığ 1 ve yeni bir düzenin kurulduğu bir dünya düzeni değil, birden fazla alanda birden fazla hegemonun olduğu bir dünya düzeninin ortaya çıkması daha olası görünmektedir.

\subsection{Yumuşak Güç: Amerikan Hegemonyasının Sonu mu?}

Soğuk Savaş'ın sona ermesiyle zirveye ulaşan ve Amerikan hegemonyasının yapıtaşı olan demokrasinin yayılması, 11 Eylül saldırıları sonrasında sekteye uğramış hatta gerilemiştir. Düşüşe geçen küresel demokrasi dalgaları, Arap Baharı ile daha da gerilemiş, 2008-2012 yılları arasında yaşanan Büyük Regresyon, ABD’nin yumuşak gücüne bakış açılarını da derinden etkilemiştir. Bazı uzmanlara göre Amerikan finansal sistemi ve buna bağlı hâkimiyeti, göreli olarak zayıflamıştır, hatta tek kutuplu dönemin sonu olarak tanımlanan ve ABD’nin statüsünü ve ideolojik gücünü de yıpratan bir çöküşten bile bahsedilebilir. ${ }^{90}$ Başka bir ifadeyle, bu olası ekonomik çöküş, Amerikan serbest piyasa kapitalizm modelinin de sonu anlamına gelmektedir. ${ }^{91} 2008$ sonrasında ABD’nin küresel politik ekonomideki konumu, genel olarak BRICS ülkelerinin (Brezilya, Rusya, Hindistan, Çin, Güney Afrika Cumhuriyeti) yükselişine odaklanmak zorunda kalmıştır. Bu konuda temel argüman, Amerikan egemenliğinin göreli olarak aşınmasıdır. Ekonomik çöküş sonrasında Çin, ABD’nin yumuşak güç üzerine tekelini

\footnotetext{
${ }^{89}$ Zha Daojiong, "China-US Relations Under Trump: More Continuity Than Change”, Asian Perspective 41, no. 4 (2017): 711.

${ }^{90} \mathrm{Bu}$ konuda güncel bir çalışma için bkz. Kantarcı, Ş. "Thoughts/Predictions On The Effect Of The Covıd-19 Pandemic Process Upon The International System". Ahi Evran Üniversitesi İktisadi ve İdari Bilimler Fakültesi Dergisi 4, (2020): 173-187.

${ }^{91}$ Roger C. Altman, "The Great Crash, 2008: A Geopolitical Setback for the West", Foreign Affairs 88, no. 1 (2009): 2 .
} 
de kırmış, Amerikan modeline alternatif olarak kendi kültürüne, diplomasisine ve kendi oluşturduğu sisteme dayanarak yumuşak gücünü geliştirme konusunda giderek ustalaşmıştır. ${ }^{92}$

Amerikan hegemonyasının gerilemekte olduğuna dair bu gibi görüşler, her dönemde tekrarlansa da, son yirmi yılda ABD’nin artık hegemonik zirvesine ulaştığı yönündeki iddialar ağırlık kazanmıştır. Bu anlayışa göre, ABD’nin zirvedeki konumu bundan sonra istikrarlı şekilde düşüş gösterecektir. Hatta bazı düşünürler, Amerikan hegemonyasının 1980’lerde tükendiğini dahi iddia etmişlerdir. Örneğin Immanuel Wallerstein'ın Modern Dünya Sistemi Teorisi'ne göre hegemonya döngüseldir ve zirveye ulaştıktan sonra, yükselen rakip iktidarlara karş1 hegemonun gücünün düşüşe geçmesi kaçınılmazdır. ABD’nin liderliğini yürüttüğü liberal hegemonik düzene yönelik ilk eleştiri, Soğuk Savaş döneminde hegemonyasının küresel anlamda geçerliliğinin sorgulanmasıyla olmuştur. Çünkü bu düzen, o dönemde sadece ABD, İngiltere, Japonya, Batı Avrupa ve Avustralya'da geçerliydi.

Bugün Çin, yükselen bir güç olsa da dünyanın geleceğindeki rolü belirsizliğini korumaktadır. ABD Ulusal İstihbarat Konseyi'nin analizine göre, Çin'in otoriter devlet konumunu koruması, uluslararası alandaki çalışmalarına, uluslararası düzenin kurallarına uymasına ve koyduğu kuralları barışçıl ve meşru temele oturtması koşullarına bağlıdır. Bu durum, aslında bazı Amerikan liderlerin hedeflerinden çok da uzak değildir. Örneğin ABD dışişleri eski bakan yardımcısı Robert Zoelick, Eylül 2005'te Çin'in başarısını ve barışçıl refahını borçlu olduğu mevcut uluslararası sistemi güçlendirme sorumluluğu olduğunu söylemiştir. ${ }^{93}$

Trump, seçilmesinin ardından aktif şekilde AB'nin dağılmasından yana politika izlemiş, NATO gibi ABD destekli küresel güvenlik ittifaklarının sürekliliğini sorgulamış ve küreselleşmeyi tersine çevirmekle tehdit eden bir ekonomik milliyetçiliği savunmuştur. ${ }^{94}$ Trump'ın başkan seçilmesi ve Brexit'in etkisiyle neo-liberal düzen yeniden düşüşe geçmiştir (Stokes, 2018, 133-4). Bu süreçte, hem Batı ülkeleri dişındaki ülkelerde anti-demokratik liderler, hem de Batı ülkelerindeki aşırı sağcı liderler güç kazanmış, aynı zamanda liberal

\footnotetext{
${ }^{92}$ Layne, "The US-Chinese power shift and the end of the Pax Americana", 101.

${ }^{93}$ Kurlantzick, Charm Offensive: How China's Soft Power Is Transforming the World, 153.

${ }^{94}$ Peter Dombrowski ve Simon Reich, "Does Donald Trump have a grand strategy?", International Affairs 93, no. 5 (01 Eylül 2017): 251-66.
} 
değerlerin temeli de ağır darbe almıştır. Bu koşullar, başka bölgelere küresel güç kaymasını kolaylaştırmaktadır.

Trump yönetimi, anayasal normları ve demokratik kurumları ezerek ABD'nin uluslararası itibarını zedelemiş ve Amerikan Çağı'nın sona ereceği yönündeki endişeleri arttırmıştır. ${ }^{95}$ Trump, temel olarak “Önce ABD” görüşüne sahipken, mevcut küresel rejimlere şüpheyle yaklaşmıştır. ABD’nin uluslararası liberal sistemden dolayı haksızlığa uğradığına inanmakla birlikte, küresel ekonomideki dezavantajlı konumunu telafi etmek doğrultusunda öncelikli olarak uluslararası taahhütlerden kurtulma amacını gütmüştür. ${ }^{96}$

\subsection{Yeni Bir Asya Yüzyılı mı?}

Aslında, Amerikan hegemonyasının zayıflayıp, yerini Asya ülkelerinin hegemonyasının alacağına dair görüşler bir dizi soruyla başlamaktadır: Yeni bir Asya yüzyılına doğru mu ilerliyoruz? Batı ülkeleri gelecekte daha az zengin ve daha az nüfuz sahibi mi olacak? Ya da yazarların ve akademisyenlerin inatla ısrar ettikleri ve Amerikan halkının artık inanmaya başladığı gibi Amerikan hegemonyasının düşüşü gerçek mi? Öyle ki kamuoyu yoklamalarına göre Amerikan halkının çoğu, Asya ülkelerini Asyalıların kendilerini gördüğünden daha güçlü bir konumda görmektedir.

ABD’nin Asya'daki bölgesel ekonomik etkinliği azalırken, Çin'in yükselişi çarpıcı olmuştur. 1993 y1lında ASEAN'ın ticaretinin yüzde 2'sini Çin oluştururken, yüzde 18'ini ABD oluşturmaktaydı. Ancak 2013 yılına kadar ASEAN ticaretinin Amerikan malları içindeki payı yüzde 8,2'ye kadar gerilerken, Çin'in payı ise yüzde 14'e yükselmiştir. ${ }^{97}$ Çin'e karşı artan ekonomik bağımlılık, 2016'dan bu yana Malezya, Kamboçya, Myanmar ve Filipinler gibi ülkelerin yönlerini ABD'den Çin'e çevirmelerine neden olmuştur.

Seçilmesinden kısa bir süre sonra, Ocak 2017'de Trans-Pasifik Ortaklı̆̆ı'ndan (TPO) ABD’nin imzasını çekerek anlaşmanın yürürlüğe girmesine engel olan Trump, Çin'e, Batı'nın uluslararası hâkimiyetini kırma yolunda büyük bir koz vermiştir. Böylece Çin, 2012'de TPO’yu dengelemek amacıyla oluşturduğu Bölgesel Kapsamlı Ekonomik Ortaklık’ın (BKEO) Asya

\footnotetext{
95 Eliot A. Cohen, "How Trump Is Ending the American Era", The Atlantic, 12 Eylül 2017, https://www.theatlantic.com/magazine/archive/2017/10/is-trump-ending-the-american-era/537888/ (28.5.2019). 96 Thomas Wright, “Trump's 19th Century Foreign Policy", POLITICO Magazine, 20 Ocak 2016, https://www.politico.com/magazine/story/2016/01/donald-trump-foreign-policy-213546 (18.4.2019).

97 ASEAN, ASEAN Economic Community Chartbook 2017 (Jakarta: The ASEAN Secretariat, 2017), http://www.aseanstats.org/category/asean-economic-chartbook/ (15.4.2019).
} 
Pasifik’teki 16 ülkesiyle görüşmelere yeniden başlama firsatı bulmuştur. 15 Kasım 2020'de yürürlüğe giren ve Çin'in ilk çok taraflı serbest ticari anlaşması olan BKEO, dünya nüfusunun GSYİH'nin yaklaşık yüzde 30'unu kapsayan dünyanın en büyük ticari bloku olmuştur. ${ }^{98}$

Asya ekonomisinin dünyadaki ağırlığını arttıran hızlı ekonomik büyümeye paralel olarak, kıtadaki yoksulluk da çarpıcı şekilde azalmaktadır. Buna karşın, ekonomik güç kaymasının Batılı ülkelerden Asya ülkelerine ciddi oranlarda gerçekleşmediği görülebilir. Ayrıca Asya ekonomilerinde önemli yapısal eksiklikler bulunmaktadır. Örneğin her ne kadar düşük maliyetli olduğu için tercih sebebi olsa da Çin ürünlerinin kalitesi, dünya standartlarının altındadır ve donanım/yazılım teknolojileri gibi alanlarda $\mathrm{ABD}$ hala piyasaya hakimdir. Kısacası Asya ülkelerinin Batılı ülkeleri yakalayabilmesi için hala almaları gereken uzun bir yol vardır. Asya'nın siyasi parçalanmışlığı da bu durumu dolaylı yönden etkilemektedir. Asya ülkelerinin arasındaki tarihi derin husumetler, birbirlerinin yükselişlerini engelleme çabalarına yol açmaktadır. Çin'in Japonya’ya karşı tutumu ve Hindistan'ın Çin ve Pakistan gibi komşu ülkeleriyle olan sorunları bu duruma örneklerdir.

CIA ile ilişkili RAND Corporation, Çin'in ABD ile arasındaki askeri güç farkını henüz tam anlamıyla kapatabilmiş olmamasına rağmen aradaki boşluğu daralttığını ifade etmiştir. ${ }^{99}$ Bu doğrultuda 2020’lerde Doğu Asya bir güç kaymasına şahitlik edebilecektir. Bununla birlikte ABD'nin olası bir Asya yüzyılına liderlik edip edemeyeceği bir muammadır. Asya-Pasifik ülkeleri, genel anlamda ABD ve Çin arasında sıkışmıştır. Çünkü çoğu, gelecekte ekonomik bakımdan Çin'e bağlı olacakken, ABD'nin güvenlik şemsiyesi altında olmayı ummaktadır. ${ }^{100}$

\section{Sonuç}

İkinci Dünya Savaşı'ndan daha güçlü bir ordu ve ekonomiyle çıkan ABD, Truman Doktrini ve Marshall Yardımları gibi politikalarla, Batı Avrupa'yı da yedeğine alarak kısa zamanda Doğu Blokuna karşı küresel hegemon konumuna yükselmiştir. ABD hala, günümüzde dünya çapında güç projeksiyonlandırma yeteneğine sahip olan tek güçtür ve yakın gelecekte de

\footnotetext{
${ }^{98}$ Charmaine Ng, "15 Countries, Including Singapore, Sign RCEP, the World's Largest Trade Pact”, The Straits Times, 16 Kasim 2020, https://www.straitstimes.com/singapore/politics/15-countries-including-singapore-signrcep-the-worlds-largest-trade-pact (12.1.2020).

${ }^{99}$ Eric Heginbotham, The U.S.-China Military Scorecard: Forces, Geography, and the Evolving Balance of Power, 1996-2017 (Santa Monica, CA: RAND, 2015), 321.

${ }^{100}$ G. John Ikenberry, “American Hegemony and East Asian Order”, Australian Journal of International Affairs 58, no. 3 (Eylül 2004): 354.
} 
bu konumunu sürdüreceği düşünülmektedir. Şu anda Çin veya başka bir devlet, askeri olarak ABD ile rekabet edecek güçte değildir. Ekonomik açıdansa diğer bazı devletler, ABD ile rekabet edebilecek güce ulaşmıştır ve bu bağlamda dünya çok kutuplu bir hal almaktadır. Örneğin, Avrupa ekonomik bir varlık olarak davranabildiğinde ABD ile aynı ölçektedir; diğer yandan Japonya da hâlâ önemli bir rol oynamaktadır. Hükümetlerin kontrolü dışındaki ulusötesi ilişkilere bakıldığında, uluslararası terörizm, iklim değişikliği gibi konularda dünyayı çok kutuplu veya tek kutuplu olarak adlandırmak giderek anlamını yitirmektedir.

Bir süper güç olarak $\mathrm{ABD}$, sadece kendi çıkarlarını değil, aynı zamanda küresel güvenliği ve refahı da desteklemektedir. $\mathrm{ABD}$, ittifak ağları ve $\mathrm{BM}$ Güvenlik Konseyi aracılığıyla ulus devletlerin egemenliğini korumuştur. Dahası, kapitalizmin ticaret anlaşmaları ve Dünya Ticaret Örgütü ile Uluslararası Para Fonu gibi kurumlar aracılığıyla yayılmasını sağlamıştır.

Washington için önümüzdeki on yıllarda en önemli stratejik sorununun Çin ile rekabet olacağı görülmektedir. Kendi lehine bir küreselleşme paradigması oluşturmaya çalışan Çin, 21. yüzyılın çok kutuplu ortamında kendisini bir dünya lideri olarak resmetmekte ve konumlandırmaktadır. Çin'in 2013 yılında 152 ülkede ve uluslararası kuruluşlarda altyapı geliştirme ve yatırımlarını arttırma amacıyla başlattığı Bir Kuşak Bir Yol Girişimi’ni güvence altına almak amacıyla askeri varlığı ve gücüyle desteklemesi, özellikle Orta Doğu, Güneydoğu Asya ve Batı Pasifik'te kurduğu ve kurmayı planladığı askeri üsler, ABD’ye küresel güç olarak rakip olma stratejisini yansıtmaktadır. Buna karşılık ABD, 11 Haziran 2021 tarihli G7 zirvesinde, Çin'in kuşak ve yol girişimine bir alternatif oluşturma planlarını açıklamış, Batılı müttefiklerini Çin'i 'çevreleme' politikasına destek vermeye üstü kapalı bir şekilde davet etmiştir. ${ }^{101}$ Çin ise, küresel konularda artık birkaç ülkenin karar verdiği devirlerin geride kaldığını belirterek bu girişimlere tepki göstermiştir.

Otokratik yönetim anlayışıyla Çin, gelecekte de Amerikan hegemonyası için tehdit oluşturacak, bunu yaparken kaderini Batılı devletlerin eline bırakan gelişmekte olan ülkeler, hatta gelişmiş ülkeler de Çin'i yeni patron olarak görebilecektir. Bu senaryoda, ABD hegemonyası sadece gerilemekle kalmayıp, hızla çözülebilir. Çin'in bu yükselişini barışçıl bir

\footnotetext{
${ }^{101}$ Patrick Wintour, "G7 Backs Biden Infrastructure Plan to Rival China's Belt and Road Initiative”, The Guardian, 12 Haziran 2021, blm. World news, http://www.theguardian.com/world/2021/jun/12/g7-global-infrastructureplan-to-rival-chinas-belt-and-road-initiative (19.6.2021).
} 
süreçle gerçekleştireceği şüphelidir. Uluslararası sistemde tek kutuplu sisteme kıyasla çift kutuplu sistem daha istikrarlı ve güvenlidir. Oluşabilecek jeopolitik kargaşaya rağmen, Amerika ile Çin'in arasında çatışma olup olmayacağını iki devletin stratejileri belirleyecektir.

Uluslararası düzenler, kuruldukları dönemlerin güç dengesini yansıtırlar. Yükselen alternatif hegemonik güç, mevcut düzene dair hoşnutsuzluğuyla bu düzeni değiştirmek isteyecek, ancak hâlihazırdaki hegemon devlet bu değişime karşı çıkacaktır. Bu durumda mevcut hegemon, küresel düzeni diğer devletin talepleri doğrultusunda revize etmezse oluşacak çatışma ortamıyla baskın devletin düzeni zayıflayacak, hatta çökecektir. Bu olası değişim sürecinin barışçıl yollarla da olsa, çatışmayla da olsa gerçekleşmesi kaçınılmazdır, ancak ne kadar süreceğini tahmin etmek zordur.

ABD, askeri gücü ve çok yönlü üstünlükleri sayesinde, şu anda hegemonik bir rakip veya koalisyonla karşı karşıya değildir. Aslında küresel büyük güçlerin çoğu ABD ile müttefiktir. Ancak ABD’nin hegemonyasını koruyabilmesi için gerekli ekonomik gücünü sürdürebilmesi ve dünya üzerindeki itibarını ve siyasi etkinliğini koruyabilmesi için gereken temel unsur, doların uluslararası rezerv para birimi özelliğini korumasıdır. $\mathrm{Bu}$ anlamda, özellikle enerji ticaretinde doların uluslararası para birimi olarak kullanımından vazgeçilmesi, Amerikan hegemonyasının çöküşünü başlatacaktır. Dünya üzerindeki fosil yakıtlara olan talebin azalması ve aynı zamanda ABD’nin saldırgan şekilde ambargo uyguladığı ülkelerin kendilerine alternatif pazarlar araması sonucu dolardan farklı para birimleriyle ticarete itmesi, doların mevcut konumunu tehlikeye atmaktadır. ABD’nin dolar hegemonyası, bu bağlamda askeri üstünlügünden daha önemlidir, çünkü hegemonyasının dolar sütununun kaldırılması, askeri olarak küçülmesine neden olacaktır. Bununla birlikte, ABD küreselleşmenin yönetiminde daha yapıcı bir yaklaşım benimsemeli, hegemonyasının devamlılı̆ııı sağlayacak yeni bir uluslararası yapı inşa etmeli, bu sisteme uygun şekilde mevcut uluslararası kurumları revize etmelidir. Trump sonrasında Biden yönetiminin ABD politikasını yeniden ayarlaması ve hegemonyasını korumak için daha uyumlu bir dış politika izlemeli ve neo-liberal politikalarında esaslı bir revizyona gitmelidir.

Son olarak, günümüz küresel dünyasında, çoğu devlet, ABD ve Çin de dâhil olmak üzere kendi refahları ve güvenlikleri için birbirlerine ekonomik anlamda tamamen bağımlı hale gelmiştir. Ülkeler, açıkça belirlenmiş dostlardan ve iyi tanımlanmış düşmanlardan oluşan bir dünyada değil, ortaklığın bir zorunluluk haline geldiği bir dünyada yaşamak zorundadır. 
IJPS, 2021: 3(3):332-368

International Journal of Politics and Security, 2021: 3(3):332-368

\section{Kaynaklar}

Abrami, Regina M., William C. Kirby, ve F. Warren McFarlan. "Why China can't innovate”. Harvard business review 92, sy 3 (2014): 107-11.

Acharya, Amitav. "Nonhegemonic international relations: A preliminary conceptualization". Centre for Governance and International Affairs University of Bristol, Working Paper (2008): 10-08.

Altman, Roger C. "The Great Crash, 2008: A Geopolitical Setback for the West". Foreign Affairs 88, sy 1 (2009): 2-14.

Arrighi, Giovanni. Globalization in World-Systems Perspective. Critical Globalization Studies. Çeviren R.P.Appelbaum ve W.I.Robinson Der. New York: Routledge, 2005.

ASEAN. ASEAN Economic Community Chartbook 2017. Jakarta: The ASEAN Secretariat, 2017. $\mathrm{http} / / / \mathrm{www}$.aseanstats.org/category/asean-economic-chartbook/ (15.4.2019).

BBC News. "Nato summit: Trump blasts Macron 'brain dead' comments as 'nasty", 03 Aralık 2019. https://www.bbc.com/news/world-europe-50641403 (12.7.2020).

Bischof, Günter. “Empire Discourses: The »American Empire« in Decline?” Kurswechsel, 2009, 5.

Bölme, Selin M. Incirlik Üssü: ABD’nin Üs Politikası ve Türkiye. İstanbul: İletişim Yayınları, 2012.

Brooks, Stephen G., ve William Curti Wohlforth. America abroad: the United States' global role in the 21st century. New York, NY: Oxford University Press, 2016.

Brzezinski, Zbigniew. Büyük Satranç Tahtası: Amerika'nın Küresel Üstünlüğü ve Bunun Jeostratejik Gereklilikleri. Çeviren Çev Y. Türedi. Ankara: İnkılap Kitabevi, 2010.

Bush, George H.W. "Address Before United Nations General Assembly". 1990. http://dosfan.lib.uic.edu/ERC/briefing/dispatch/1990/html/Dispatchv1no06.html/ (17.4.2019).

Bush, George W. "President Delivers State of the Union Address". The United States Capitol, 29 Ocak 2002. https://georgewbush-whitehouse.archives.gov/news/releases/2002/01/20020129-11.html (20.9.2020).

. "Remarks at a White House Reception for Veterans". The White House, 11 Kasim 2002. https://www.presidency.ucsb.edu/documents/remarks-white-house-reception-for-veterans (20.09.2020).

Coase, Ronald H., ve Ning Wang. "How China Became Capitalist”. Policy Report. CATO Institute, 15 Ocak 2013. https://www.cato.org/policy-report/january/february-2013/how-china-becamecapitalist (12.7.2020).

Cohen, Eliot A. "How Trump Is Ending the American Era". The Atlantic, 12 Eylül 2017. https://www.theatlantic.com/magazine/archive/2017/10/is-trump-ending-the-american$\mathrm{era} / 537888 /$ (28.5.2019).

"Comparing United States and China by Economy". Statistics Times, 19 Haziran 2021. https://statisticstimes.com/economy/united-states-vs-china-economy.php/ (25.6.2021).

Cooley, Alexander, ve Daniel H. Nexon. "How Hegemony Ends". Foreign Affairs, 30 Ocak 2021. https://www.foreignaffairs.com/articles/united-states/2020-06-09/how-hegemony-ends (11.8.2020).

Cox, Michael. "Is the United States in Decline-Again? An Essay". International Affairs 83, sy 4 (Temmuz 2007): 643-53.

Cox, Robert W. Production, Power, and World Order: Social Forces in the Making of History. Columbia University Press, 1987. 
Cullen, Patrick. "The Rebalance to Asia Under Trump". The RUSI Journal 162, sy 2 (04 Mart 2017): 815.

Çiftçi, Kemal. "Soğuk Savaş Sonrasında ABD: 'Rıza'ya Dayalı 'Hegemonya'dan ‘İmparatorluk’ Düzenine”. ZKÜ Sosyal Bilimler Dergisi, 5/10, (2009): 203-219.

Daojiong, Zha. "China-US Relations Under Trump: More Continuity Than Change". Asian Perspective 41, sy 4 (2017): 701-15.

David, Charles Philippe, ve David Grondin, ed. Hegemony or empire? the redefinition of US power under George W. Bush. Aldershot, England; Burlington, VT: Ashgate, 2006.

Davutoğlu, Ahmet. "Felsefi ve Stratejik Boyutlarıyla 11 Eylül Sonrası Dönem”. Içinde Sahibini Arayan Barış, editör B. Masis Kürkçügil. Istanbul: Everest, 2002.

Dinç, Cengiz, ve Bekir Karataş. "Amerikan Karşıtlığında Güncel Küresel Eğilimler ve Trump Etkisi”. OPUS Uluslararası Toplum Araştırmaları Dergisi 9, sy 16 (25 Aralık 2018): 1992-2032.

Dombrowski, Peter, ve Simon Reich. "Does Donald Trump have a grand strategy?" International Affairs 93, sy 5 (01 Eylül 2017): 1013-37.

Easton, Nina J. "Thunder on the Right”. American Journalism Review 23, sy 10 (2001): 32-38.

Eisenstadt, Shmuel N. "The Civilizational Dimension of Modernity: Modernity as a Distinct Civilization”. International Sociology 16, sy 3 (01 Eylül 2001): 320-40 (31.10.2020).

Emorine, Hélène. "The European Union's Defence Strategy Gets an Overhaul”. Open Canada, 15 Şubat 2018. https://opencanada.org/european-unions-defence-strategy-gets-overhaul/ (31.10.2020).

Feickert, Andrew. "The Unified Command Plan and Combatant Commands: Background and Issues for Congress". Congressional Research Service, 03 Ocak 2013. https://fas.org/sgp/crs/natsec/R42077.pdf.

Fichtner, Jan. "Perpetual Decline or Persistent Dominance? Uncovering Anglo-America's True Structural Power in Global Finance". Review of International Studies 43, sy 1 (Ocak 2017): 328.

Forbes. Global 2020: The World's Largest Public Companies", 2020. https://www.forbes.com/lists/global2000/ (25.1.2021).

Foster, John Bellamy. "The End of Rational Capitalism”. Monthly Review 56, sy 10 (01 Mart 2005): 113.

Friedman, Uri. "How to Choose Between the U.S. and China?" It's Not That Easy", 2019. https://www.theatlantic.com/politics/archive/2019/07/south-korea-china-united-statesdilemma/594850/ (13.11.2020).

Fukuyama, Francis. "History Is Still Going Our Way”. Wall Street Journal, 05 Ekim 2001, blm. Front Section. https://www.wsj.com/articles/SB1002238464542684520 (12.7.2020).

Gray, John. "John Gray: A Shattering Moment in America's Fall from Power". The Guardian, 27 Eylül 2008 , blm.

Opinion. http://www.theguardian.com/commentisfree/2008/sep/28/usforeignpolicy.useconomicgrowth (15.4.2019).

Hama, Hawre Hasan. "Is the United States Still a Global Hegemonic Power?" International Journal of Social Sciences \& Educational Studies 3, sy 2 (01 Aralık 2016): 109-17.

Hardt, Michael, ve Antonio Negri. Empire. Cambridge, Mass: Harvard University Press, 2000. 
Heginbotham, Eric. The U.S.-China Military Scorecard: Forces, Geography, and the Evolving Balance of Power, 1996-2017. Santa Monica, CA: RAND, 2015.

Huygens, Addison Daniel. American Decline and Changing Global Hegemony”. Iowa: Master Thesis of Political Science, Iowa State University, 2017.

Ikenberry, G. John. "American Hegemony and East Asian Order”. Australian Journal of International Affairs 58, sy 3 (Eylül 2004): 353-67.

International Money Fund. "World Currency Composition of Official Foreign Exchange Reserves", 2019. https://data.imf.org/?sk=E6A5F467-C14B-4AA8-9F6D-5A09EC4E62A4 (23.01.2020).

Keohane, Robert Owen. After Hegemony: Cooperation and Discord in the World Political Economy. Princeton: Princeton University Press, 1984.

Kurlantzick, Joshua. Charm Offensive: How China's Soft Power Is Transforming the World. New Haven: Yale University Press, 2007.

Kutlay, Mustafa. Global Power Shifts and Turkey- EU Relations in the Age of Hybridity. Paris: Institut du Bosphore, 2019.

Lake David. "Britanya ve Amerikan Hegemonyasının Karşılaştırılması: Gerileme Çağı Üzerine Bazı Dersler"”. Çev. Mehmet Zeki Ak ve Ünsal Ozan Kahraman, Bilgi 28 (2014): 122-38.

Lake, David A. "Escape from the State of Nature: Authority and Hierarchy in World Politics". International Security 32, sy 1 (2007): 47-79.

Layne, Christopher. "The US-Chinese power shift and the end of the Pax Americana". International Affairs 94, sy 1 (01 Ocak 2018): 89-111. doi:10/gcv72f.

Lee, John. "America Rising: Indispensible Again in Asia”. World Affairs 179, sy 1 (01 Haziran 2016): 22-29.

Liao, Rebecca. "China's New Helmsman: Where Xi Jinping Will Take the Middle Kingdom Next"'. Foreign Affairs, 2017, 1-4.

Lieber, Keir A, ve Gerard Alexander. "Waiting for Balancing: Why the World Is Not Pushing Back". International Security 30, sy 1 (Temmuz 2005): 109-39.

Longman, Martin, ve Josh Freedman. "Higher Red". Washington Monthly, 26 Ekim 2016. https://washingtonmonthly.com/magazine/novemberdecember-2016/higher-red/ (15.11.2020).

Lukyanov, Fyodor. "Is Russia's Dialogue with the EU Coming to an End?" The Moscow Times, 15 Ekim 2020, blm. Opinion. https://www.themoscowtimes.com/2020/10/15/is-russias-dialoguewith-the-eu-coming-to-an-end-a71766 (12.12.2020).

Markit, I.H.S. China to Become World's Largest Economy in 2024 Reports IHS Economics", 2014. https://news.ihsmarkit.com/press-release/economics-country-risk/china-become-worldslargest-economy-2024-reports-ihs-economics/ (17.4.2019).

Mearsheimer, John. Mearsheimer on Strangling China \& the Inevitability of War. Röportaj yapan Peter Navarro, $03 \quad$ Ekim 2016. https://www.huffpost.com/entry/mearsheimer-onstrangling_b_9417476 (28.5.2019).

Mearsheimer, John J. The Tragedy of Great Power Politics. New York: Norton Press, 2001.

Metzl, Jamie. "Trump and Global Security". Central Tibetan Administration, 05 Nisan 2017. https://tibet.net/trump-and-global-security/ (31.10.2020).

Miller, Tom. “A Chinese Bretton Woods?” Gavekal Research, 12 Haziran 2014. https://research.gavekal.com/user/login?destination=node/8800. 
Mouffe, Chantal. On the Political. London\&New York: Routledge Press, 2005.

Ng, Charmaine. "15 Countries, Including Singapore, Sign RCEP, the World's Largest Trade Pact". The Straits Times, 16 Kasim 2020. https://www.straitstimes.com/singapore/politics/15-countriesincluding-singapore-sign-rcep-the-worlds-largest-trade-pact (12.1.2020).

Norrlof, Carla. "Hegemony”. Oxford University Press, 2015.

Nye, Joseph S. "How to Deal with a Declining Russia". Project Syndicate, 05 Kasim 2019. https://www.project-syndicate.org/commentary/dealing-with-danger-of-declining-russia-byjoseph-s-nye-2019-11 (17.11.2020).

Nye, Joseph S. "Perspectives for a China Strategy”. PRISM 8, sy 4 (2020): 121-31.

Nye, Joseph S. "Should China Be 'Contained'?", 2011. http://belfercenter.hks.harvard.edu/ publication/21192/should_china_be_contained.html/ (28.5.2019).

Nye, Joseph Samuel. Is American Century Over? Cambridge: Polity Press, 2015.

Pillsbury, Michael. The Hundred Year Marathon; China's Secret Strategy to Replace America as the Global Superpower. New York: Henry Holt and Company, 2015.

“QS World University Rankings 2021”. Top Universities, 2020. https://www.topuniversities.com/university-rankings/world-university-rankings/2021 (13.11.2020).

Quinn, Adam. "The Art Of Declining Politely: Obama's Prudent Presidency and The Waning of American Power"'. International Affairs 87, sy 4 (2011): 803-24.

Quinn, Adam ve Kitchen ve Nicholas. "Understanding American Power: Conceptual Clarity, Strategic Priorities, and the Decline Debate"”. Global Policy 10, sy 1 (2019): 5-18.

Richter, Konstantin. “Angela Merkel's New Job: Global Savior”. POLITICO, 17 Kasım 2016. https://www.politico.eu/article/donald-trump-angela-merkel-the-last-leader-of-the-free-world/ (12.7.2020).

Shin, Beom Shik. "Russia's Place in the Changing Strategic Triangle in the Post-Cold War Northeast Asia: From an Outcast to a Strategic Player?" The Journal of International and Area Studies 22, sy 2 (2015): 109-34.

Shuster, Simon. "Why Angela Merkel Isn't Ready to Be the 'Leader of the Free World". Time, 12 Aralık 2016. https://time.com/4598467/angela-merkel-donald-trump-liberal-democracy/ (25.6.2021).

Silver, Laura, Kat Devlin, ve Christine Huang. "China's Economic Growth Mostly Welcomed in Emerging Markets, but Neighbors Wary of Its Influence". Pew Research Center, Aralık 2019. https://www.pewresearch.org/global/2019/12/05/attitudes-toward-china-2019/.

Singh, Robert. "The Exceptional Empire: Why the United States Will Not Decline - Again". International Politics 45, sy 5 (01 Eylül 2008): 571-93.

"SIPRI Military Expenditure Database". Stockholm International Peace Research Institute, 2020. https://www.sipri.org/databases/milex (11.8.2020).

Spetalnick, Matt. "China High on Agenda for Obama's Asia Tour - Aide”. Reuters, 03 Kasım 2010, blm. Internal Reuters India Online Rpt Special Events 1. https://www.reuters.com/article/idINIndia52631620101103 (17.4.2019).

Stokes, Doug. "Trump, America Hegemony and the Future of the Liberal International Order". International Affairs 94, sy 1, (2018): 133-150. 
Sümer, Gültekin. "Amerikan Dış Politikasının Kökenleri ve Amerikan Dış Politik Kültürü”. Uluslararası İlişkiler Dergisi 5, sy 19 (2008): 119-44.

The World Bank. "Exports of goods and services (BoP, current US\$)", 2019. https://data.worldbank.org/indicator/BX.GSR.GNFS.CD/ (12.6.2020).

. "GDP, PPP (Current International \$) - China, United States, European Union”, 2019. https://data.worldbank.org/indicator/NY.GDP.MKTP.PP.CD (25.5.2021).

- "High-technology exports (\% of manufactured exports)", 2019. https://data.worldbank.org/indicator/TX.VAL.TECH.MF.ZS?\%20locations=US-RU (17.11.2020).

"Trade (\% of GDP)", 2019. http://data.worldbank.org/indicator/ NE.TRD.GNFS.ZS?end=2020\&start=1991/ (12.9.2020).

-. "World Bank in Russia - Overview". Text/HTML. World Bank, 2020. https://www.worldbank.org/en/country/russia/overview (17.11.2020).

Thucydides. Peloponnessos Savaşları. Çeviren Furkan Akderin. İstanbul: Belge, 2020.

Wallerstein, Immanuel Maurice. The Politics of the World-Economy. Cambridge: Cambridge University Press, 1984.

Wintour, Patrick. "G7 Backs Biden Infrastructure Plan to Rival China's Belt and Road Initiative". The Guardian, 12 Haziran 2021, blm. World news. http://www.theguardian.com/world/2021/jun/12/g7-global-infrastructure-plan-to-rival-chinasbelt-and-road-initiative (19.6.2021).

Wolf, Martin. "Three years and new fault lines threaten". Financial Times, 13 Temmuz 2010, blm. Opinion. https://www.ft.com/content/39c67712-8eb1-11df-8a67-00144feab49a (18.4.2019).

Wright, Thomas. "Trump's 19th Century Foreign Policy". POLITICO Magazine, 20 Ocak 2016. https://www.politico.com/magazine/story/2016/01/donald-trump-foreign-policy-213546 (18.4.2019).

"WTO successfully concludes negotiations on China's entry". World Trade Organization, 17 Eylül 2001. https://www.wto.org/english/news_e/pres01_e/pr243_e.htm (21.11.2020).

Xiankui, Chen, ve Tang Wei. "Coming collapse of the hegemonic world". China Daily, 12 Eylül 2008. http://www.chinadaily.com.cn/opinion/2008-09/12/content_7021668.htm (21.12.2020). 